Illinois State University

ISU ReD: Research and eData

Theses and Dissertations

6-14-2018

\title{
Assessing the Experiences of Women who have Suffered Intimate Partner Violence Living in Shelters
}

Queencilla N. Hammond

Illinois State University, queencillahammond@gmail.com

Follow this and additional works at: https://ir.library.illinoisstate.edu/etd

Part of the Criminology Commons, and the Criminology and Criminal Justice Commons

\section{Recommended Citation}

Hammond, Queencilla N., "Assessing the Experiences of Women who have Suffered Intimate Partner Violence Living in Shelters" (2018). Theses and Dissertations. 926.

https://ir.library.illinoisstate.edu/etd/926

This Thesis is brought to you for free and open access by ISU ReD: Research and eData. It has been accepted for inclusion in Theses and Dissertations by an authorized administrator of ISU ReD: Research and eData. For more information, please contact ISUReD@ilstu.edu. 


\section{ASSESSING THE EXPERIENCES OF WOMEN WHO HAVE SUFFERED INTIMATE PARTNER VIOLENCE LIVING IN SHELTERS}

\section{QUEENCILLA N. HAMMOND}

\section{Pages}

According to the Centers for Disease Control on National Intimate Partner and Sexual Violence in 2010, more than 1 in 3 women (35.6\%) and more than 1 in 4 men $(28.5 \%)$ in the United States have experienced rape, physical violence, and/or stalking by an intimate partner in their lifetime. Throughout history, someone they knew has most often victimized women. Over the past thirty years, feminist organizers of the domestic violence (DV) movement powered public awareness regarding the prevalence of intimate partner violence (IPV) dominantly. This led to the development of a network of shelters and other support services for victims, and altered the criminal justice system's response to survivors (Goodman \& Epstein, 2008).

Homelessness in the lives of intimate partner victims cannot be underestimated as violence in the homes of women is one of the factors leading to their homelessness (Bassuk, Buckner, Weinreb, Browne, Bassuk, Dawson \& Perlojf, 1997). This study presents a qualitative study of the subjective experiences of women who have survived intimate partner violence and are staying at shelters. In-depth, semi-structured interviews were conducted with four survivors. The interviews highlighted the forms of support the women received as shelter residents, and their perceptions on improvement strategies to make their stay in shelters more successful. Findings portrayed that women appreciated the assistance they received to meet their physical, emotional, spiritual and psychological needs. However, residents emphasized emotional and 
physical needs as paramount in the forms of support they received. Suggestions to make shelter stay of residents more successful included encouraging support groups for survivors and children, as well as a reduction in restrictions that governed shared spaces of shelter residents.

KEYWORDS: Intimate partner violence, women, survivors, shelters, subjective experiences 


\title{
ASSESSING THE EXPERIENCES OF WOMEN WHO HAVE SUFFERED INTIMATE \\ PARTNER VIOLENCE LIVING IN SHELTERS
}

\author{
QUEENCILLA N. HAMMOND
}

\author{
A Thesis Submitted in Partial \\ Fulfillment of the Requirements \\ for the Degree of \\ MASTER OF SCIENCE \\ Department of Criminal Justice Sciences \\ ILLINOIS STATE UNIVERSITY
}

2018 
(C) 2018 Queencilla N. Hammond 


\title{
ASSESSING THE EXPERIENCES OF WOMEN WHO HAVE SUFFERED INTIMATE PARTNER VIOLENCE LIVING IN SHELTERS
}

\author{
QUEENCILLA N. HAMMOND
}

COMMITTEE MEMBERS:

Shelly Lynn Clevenger, Chair

Dawn Beichner

Ashley Farmer 


\section{ACKNOWLEDGMENTS}

My first most thanks goes to the Almighty God, for granting me the opportunity to study abroad in the United States. Pursuing a master's program would not have been possible without His continues grace and mercies. I am forever grateful to Him. I would like to extend special thanks to Prof. Shelly Clevenger, my thesis chair, for agreeing to work with me, and for her selfless support right from my thesis committee creation. I have come this far because of her counsel, guidance, and relentless understanding regardless of the challenges I faced in bringing this research into fruition. To Profs. Dawn Beichner and Ashley Farmer, your all out support, well-meaning contributions and flexibility throughout this study is deeply appreciated.

My gratitude also goes to all the women who voluntarily shared their lives with me. Your courage as survivors will always be remembered. Dustin Richardson, thank you for being very helpful. I am also grateful for my family in Ghana and abroad. Your love, prayers and encouragement in diverse ways keeps me going.

Finally, to my beloved John Kotey, many thanks for standing by me through thick and thin. My gratitude also goes to all my friends in Ghana and abroad for all the support throughout my graduate studies. I appreciate you all.

Q. N.H 


\section{CONTENTS}

Page

ACKNOWLEDGMENTS

$\begin{array}{ll}\text { CONTENTS } & \text { ii }\end{array}$

TABLES $\quad$ V

CHAPTER

I. INTRODUCTION

II. LITERATURE REVIEW

Definition and Prevalence of Intimate Partner Violence 4

Intimate Partner Violence in the Past 5

History of Homeless Women in America $\quad 8$

Colonial America, the Nineteenth Century to the Present 9

$\begin{array}{ll}\text { Development of Domestic Violence Shelters } & 12\end{array}$

$\begin{array}{ll}\text { Nature of Shelters } & 15\end{array}$

$\begin{array}{ll}\text { Shelter Rules } & 16\end{array}$

Coping with Shelter Rules 19

$\begin{array}{ll}\text { Children Living in Shelters } & 19\end{array}$

Shelter Residents Account of Experiences $\quad 20$

$\begin{array}{ll}\text { Theoretical Framework } & 24\end{array}$

$\begin{array}{ll}\text { III. METHODS } & 27\end{array}$

$\begin{array}{ll}\text { Sample } & 27\end{array}$

$\begin{array}{ll}\text { Recruitment of Participants } & 28\end{array}$

$\begin{array}{ll}\text { Participant Experiences } & 30\end{array}$ 
$\begin{array}{ll}\text { Improvements } & 31\end{array}$

$\begin{array}{ll}\text { Instrumentation } & 31\end{array}$

$\begin{array}{ll}\text { Analysis } & 33\end{array}$

$\begin{array}{ll}\text { IV. RESULTS } & 35\end{array}$

$\begin{array}{ll}\text { Previous Shelter Experience } & 35\end{array}$

$\begin{array}{ll}\text { Current Shelter Experience } & 40\end{array}$

Forms of Support 44

Relationships Built During Shelter Stay 48

Impact of Shelter Living on Family Life 49

$\begin{array}{ll}\text { Learning Experiences } & 50\end{array}$

$\begin{array}{ll}\text { Suggestions on Improvements } & 51\end{array}$

Similar and/or Differences in Living Conditions at Shelter from Original

Residence 53

Opinion of Shelters Prior to Shelter Stay 55

$\begin{array}{ll}\text { Summary } & 57\end{array}$

$\begin{array}{ll}\text { V. DISCUSSION } & 61\end{array}$

$\begin{array}{ll}\text { Limitations } & 65\end{array}$

$\begin{array}{ll}\text { Recommendations and Conclusion } & 67\end{array}$

$\begin{array}{ll}\text { REFERENCES } & 74\end{array}$

$\begin{array}{ll}\text { APPENDIX A: INTERVIEW GUIDE } & 86\end{array}$

$\begin{array}{ll}\text { APPENDIX B: POSTER FOR INTERVIEW } & 88\end{array}$

APPENDIX C: VOLUNTARY INFORMED CONSENT FORM FOR INTERVIEW 90 


\section{TABLES}

Table

Page

1. Interview Participants

30 


\section{CHAPTER I: INTRODUCTION}

According to the Centers for Disease Control on National Intimate Partner and Sexual Violence in 2010, more than 1 in 3 women (35.6\%) and more than 1 in 4 men $(28.5 \%)$ in the United States have experienced rape, physical violence, and/or stalking by an intimate partner in their lifetime. Throughout history, women have been most often victimized by someone they knew. Over the past thirty years, feminist organizers of the domestic violence (DV) movement powered public awareness regarding the prevalence of intimate partner violence (IPV)

dominantly. This led to the development of a network of shelters and other support services for victims, and altered the criminal justice system's response to survivors (Goodman \& Epstein, 2008).

Homelessness in the lives of intimate partner victims cannot be underestimated as violence in the homes of women is one of the factors leading to their homelessness (Bassuk, Buckner, Weinreb, Browne, Bassuk, Dawson \& Perlojf, 1997). According to Haber and Toro (2004), the statistics that estimates rates of homelessness up to eight percent among adults is based on persons who have spent nights in homeless shelters, on the streets, or at other locations, not suitable for human residence. This is termed iliterally homelessi (Toro, 1998). This term is limited and leaves out women and children who resort to sleeping in the couches of friends, neighbors, and family members every night or resolve to stay with their abusers when emergency shelters have filled up. Women who stay in rural areas where there are no shelters and others who exchange sex for a place to sleep form part of a huge hidden homeless population (Evans $\&$ Forsyth, 2004). In a rigorous study on homeless women, researchers reveal high rates of abuse and victimization that homeless women had to endure prior to, during and after phases of 
homelessness. The researchers mention that the rates of victimization among homeless women remains unchanged although rates of victimization in the United States have generally decreased (Lee \& Schreck, 2005). Research also emphasizes that homeless women often report multiple episodes of violent victimization right from their childhood through adulthood, caused by numerous perpetrators (Browne \& Bassuk, 1997; Goodman, 1991; Goodman, Dutton \& Harris, 1995; Felix, 2004; Lee \& Schreck, 2005; Stermac \& Paradis, 2001; Wenzel et al., 2004).

A majority of women have the fear of losing their children once they gain admission into shelters (Edelman \& Mihaly, 1989). For other mothers, shelter living brings upon them, the stigma of being labeled as homeless and the opinion of outsiders that family and friends have neglected the homeless (Gerson, 2006). The increasing number of homeless women living in a household of friends and relatives and sometimes accompanied by their children have their stays often short-lived. Misunderstandings and overcrowding becomes a burden for all members present. Homeless women describe how this situation wears out their hosts as one does not only sleep in the couches of friends and relatives but also eats a couple of meals in the house of friends and relatives. More so, people who are often willing to offer housing to homeless friends and relatives are often economically distressed, inadequately housed, and have very high possibilities of going homeless themselves (Marin \& Vacha, 1994). Healthcare facilities, law enforcement agencies, nonprofit organizations, schools that meet the needs of victims' children, and effective public policy are a number of areas communities can strengthen in order to make collaborative efforts to address the issue of domestic violence (Social Issue Report, 2011).

The research aims at closing the gap in the existing literature as majority of studies on intimate partner violence fail to address the subjective accounts of domestic violence victims living in shelters and rather focus on the awareness of DV, its prevalence and effects as a social 
issue. Many shelters have undisclosed locations for security concerns and this research sought to identify battered women's experiences from their own accounts as residents of shelters, the forms of support made available to them in the shelter, the most helpful form(s) of support and what more services in their opinion as residents can improve their experiences. The study was exploratory.

In order to successfully attain the goals of this study, the researcher conducted four semistructured qualitative interviews with survivors of intimate partner violence. Purposive sampling was employed to recruit participants for this research at homeless shelters in BloomingtonNormal, Illinois. The researcher conducted face-to-face interviews with participants from one of the shelters, which granted the researcher admittance for the purpose of the study. An interview guide (Appendix A) was used to obtain information from the participants about their experiences while residing in the shelter. The use of the interview guide ensured that all major themes were discussed. More so, every participant was allowed to freely share their time in the shelter in their own words.

The findings from this study could guide management of the local domestic violence shelters and regular shelters, to put in place measures that would improve the services they offer clients and residents. Results from the study for policy makers could also lead to the scaling up of prevention programs, knowing which ones work best and the ones to be discarded in the fight to prevent domestic violence. More so, the study would also contribute to knowledge in order to fill the gap on domestic violence research that predominantly focuses on domestic violence shelters to the neglect of regular shelters, which also house survivors of intimate partner violence. 


\section{CHAPTER II: LITERATURE REVIEW}

This chapter considers a review of the literature on intimate partner violence in the United States. The researcher first discusses the definition and prevalence of intimate partner violence, gives an account of intimate partner violence in the past, the history of homeless women in America; from colonial America through the nineteenth century to present times. Other topics discussed in the chapter are development of domestic violence shelters, the nature of shelters, shelter rules, coping of women with shelter rules, children living in shelters and the theoretical framework of the study.

\section{Definition and Prevalence of Intimate Partner Violence}

Intimate partner abuse (IPA), also known as intimate partner violence (IPV) includes a wide range of behaviors meant to cause harm and are perpetrated within the context of an intimate relationship. These abusive behaviors include physical, sexual, emotional, psychological, and financial harms that usually occur in a repetitive pattern. The term intimate partner refers to a current or former spouse, dating, or otherwise romantically involved individual. These relationships may include members of opposite or same-sex/gender (i.e., heterosexual or gay/lesbian relationships) and involve those who exist outside of the gender binary (i.e., transgender). Cases of intimate partner violence are disturbingly high, even though there are several instances that are underreported. The most current estimates of IPA reveal that more than one in three women and one in four men have been physically abused, raped, and/or been stalked by an intimate partner at some point in their lifetime (Black, Basile, Briedling, Smith, Walters, Merrick, Chen \& Stevens, 2011). 
With respect to psychological or emotional violence, across their lifetime, nearly half of all men and women in the USA have experienced psychological aggression where the intimate partner is the perpetrator (Black et al., 2011). Approximately one in ten women has been raped by an intimate partner in her lifetime (Black et al., 2011). IPA has resulted in 2 million injuries and 1,300 deaths annually for women alone in the USA (Centers for Disease Control and Prevention, 2003). Additionally, intimate partner homicides account for approximately $40 \%$ of all murders of women in the USA (Campbell, Webster, Koziol-McLain \& Bloc, 2003).

\section{Intimate Partner Violence in the Past}

According to Western history, IPA was not considered a social problem and was dominantly regarded as an accepted means for husbands to discipline their wives. One of the earliest examples of this is reflected in "The Laws of Chastisement" that date as far back as 753 BCE. These Roman laws backed provisions that permitted husbands to beat their wives for any reason they believed necessitated beatings. A husband could beat his wife as long as he could utilize a branch, stick, or rod that was no thicker than the circumference of his thumb (Lemon, 1996). In another instance, the 1824 Mississippi Supreme Court case Bradley v. State, the court curbed a husband's right to beat his wife to moderate discipline and only to be used in cases of emergency (Martin, 1976). It took 47years before the first two states; Alabama and Massachusetts completely restrained the rights of a husband to beat his wife (Schechter, 1982). [Case Study]

In an important case, People v. Liberta, a court in New York heard the case of Mario Liberta who had been charged with the crime of raping his wife, Denise Liberta. The couple had been married for two years before the abuse began. In 1980, Denise requested and obtained an order of protection that forced Mario to vacate their home. Mario was granted visitation rights to 
their only child. In early 1981, Mario requested a visitation from their son and Denise agreed as long as he could pick them up and take them to the hotel in which the visit would take place. She asked that a friend of Mario's be present for the duration of the visit. Upon their arrival at the hotel, the friend left, making it possible for Mario to attack Denise. Mario did not only threaten to kill her, he also raped her, demanding that she made their son watch. Mario claimed marital exemption to rape and sodomy laws as a defense mechanism. Even though the trial court dismissed the charge, the appellate court argued that marriage was not a legal defense to rape or sodomy and convicted him. The court stated that “...a marriage license should not be viewed as a license for a husband to forcibly rape his wife with impunity. A married woman has the same right to control her own body as does an unmarried woman." (People v. Liberta, 64 N.Y.2d 152, 474 N.E.2d 567, 485 N .Y.S.2d 207, 1984).

[End Case Study]

The United Nations Development Fund for Women estimates that at least one of every three women worldwide will be beaten, raped or otherwise abused during her lifetime. In most situations, the perpetrator is a member of her own family (The United Nations Development Fund for Women, 2003). Prior to the 1960s, women who were victims of spousal abuse found themselves in the same shelters as catastrophe victims, alcoholics, and all other homeless victims, as the Salvation Army, church homes, and other homeless shelters were their only options for shelter. Unfortunately, on many occasions, these assistance centers were full to capacity and turned battered women and their children away. Most of these shelters were also inconsiderate towards the needs of women with abusive partners, often holding the women responsible for their victimization (Schechter, 1982). 
In the 1960s and 1970s, second wave feminism and the Battered Women's Movement increased the awareness of domestic violence. Intimate Partner Violence shelters emerged directly from the philosophical and political core of the feminist DV movement. Survivors usually created and run small operations as early shelters. Shelter staff encouraged a sociopolitical understanding of DV, focused on consciousness-raising efforts and sisterhood, renounced hierarchical power structures, and put in much effort to stay independent of outside service providers and funders who, they believed, completely preserved a patriarchal system that oppressed women (Epstein, Russell, \& Silvern, 1988).

Shelters were safe havens for survivors and their children who lived for as long as they needed in order to piece their lives back together. However, as shelters increased rapidly and more and more women sought help from them, shelter advocates had no option than to seek support from mainstream sources of funding. This included government agencies, leading to shelters becoming more and more accountable to bureaucracies. Mainstream funders stood in contrast to early domestic violence activists. They believed shelters provide services, residents are clients, and staff or volunteers are employees (Epstein, Russell, \& Silvern, 1988). They also demanded that staff recruited professionals instead of survivors; evaluate success based on definite externally defined criteria, such as securing stable housing or leaving an abusive relationship; and required screening for potential shelter residents (Chang, 1992; Haaken \& Yrugai, 2003).

According to Schechter (1982), early advocates were of the view that a culture dominated by men led to women being controlled and maltreated in their own homes and in society, women underrated, seen as inferior to men and treated like their property. Advocates therefore decided not to only view domestic violence as an issue between two partners in a relationship but went 
beyond a focus on keeping individual women safe to drawing attention to the macro, social level causes of violence against women, including opinions of societal members regarding gender roles and equality (Chang, 1992; McDonald, 2005; Schechter, 1982). They also emphasized awareness-raising interventions that were geared towards empowering domestic violence survivors and promoting a communal struggle against an unfair and patriarchal system (Schechter, 1982). Nowhere was this more apparent than in shelters, a core part of the domestic violence response (Glenn, 2010).

A shelter is a safe place for women to go to escape the fear of physical attack and damage to their bodies. Fleming (1979) explains:

A shelter is a sanctuary where a woman who has suffered a loss of self-esteem and selfconfidence can find people who are committed to rebuilding the positive self-image necessary for her to regain control of her life. A shelter can be a place where a woman who has lived in fear and isolation can find security and safety, as well as the love and support of other women who are struggling to rebuild lives shattered by domestic violence. A shelter can and should serve as a protective community to which residents can turn for confidential support, encouragement, and assistance (pp.354-355). Women who run to shelters often find support amongst other shelter residents who they share similar experiences with. They form bonds to survive their experiences and to reshape their lives guided by shelter rules and resources.

\section{History of Homeless Women in America}

Since the independence of the United States of America, the homeless had existed. Hopper states, "throughout most of our history the homeless have been regarded at least with indifference and often with contempt, fear, and loathing.'(McNamara, 2008, p. 77). Both men and women have suffered homelessness throughout history, but more information about males is 
available, as "homeless women have been something of a sociological mystery." The lack of documentation pertaining to women results in missing information in several books regarding homelessness among women. These gaps are typically filled with general information about the concept of homelessness, the majority of which specifically pertains to males. It is uncertain exactly why homeless women have been overlooked throughout most of history. Notably, homeless women throughout history have been frowned upon, despised, and labeled as witches, prostitutes, and the stereotype that survives today, the mentally ill bag lady (McNamara, 2008).

\section{Colonial America, the Nineteenth Century to the Present}

This era had a homeless population consisting primarily of single men and women. Usually, men served as artisans, mariners, and laborers whereas women played the role of domestic servants in the society (Wright, 1989). Women's status in society was defined by their roles as mothers and wives, and those who did not fulfill these roles were disrespected and undeserving of help or relief. Poor women were often denied residency and economic relief once they did not heed to society's idea of family ethics. Many unmarried women living on their own were immediately stereotyped as likely prostitutes, immoral and a social disease. These factors made it very cumbersome for married women to prove themselves to town officials (McNamara, 2008). In the nineteenth century, poverty was connected with criminality, insanity, and other moral defects leading to a form of evil. Homeless persons were hardly tolerated in the society and the police often blamed the homeless for crimes as they brainstormed for solutions to crime. The poor was barely offered any form of support at the time as this was seen as condoning idleness, weakness, or laziness amongst the homeless (Golden, 1992). Even though offering help to the poor was not encouraged, some institutions were still providing a form of relief to the 
homeless. Charities were usually religiously based and were capable of providing for only a small number of people.

These institutions created two groups; worthy and unworthy poor, helping only those thought to be acceptable, which usually included the sick, the elderly, and children. Unmarried mothers, abandoned wives, and widows in a disreputable neighborhood were denied relief because they did not uphold the woman's responsibility to the family ethics. Women were viewed as part of a cult of domesticity, and those who were unable to comply with the family ethic were deemed undeserving and immoral (McNamara, 2008). Late nineteenth century homeless population were gathered together to stay in skid row areas. Skid row areas (shanty towns, cheap rooming areas and saloons) suddenly emerged in a number of cities to provide homes for the homeless and transient individuals in search of seasonal industrial work. Women traveling alone on the roads faced many of the same concerns as homeless women in cities, such as obtaining food and money, as well as the dangers presented by men. Rape and abuse were common crimes committed against homeless women (Cowal, Shinn, Weitzman, Stojanovic \& Labay, 2002).

Men often viewed homeless women as common property and had little respect for them. Some women voluntarily used their sexuality as a means to get what they needed from men, like food or "hitching". Others believed women did not necessarily have to give themselves to men but rather, it was easier for women to survive the hardships that came with living on the road if she was not too particular about her surroundings. In the 1800s, alcohol was a major factor that contributed to homelessness as abandoned or widowed women often turned to alcohol for comfort and help in handling their situation. Homeless women had little clues on how to sustain themselves, and any woman abandoned or widowed by her husband was doomed to eviction as a 
result of her inability to pay rent (Golden, 1992). Although homeless women were few in number during the 1950s, those present were characterized by their invisibility and stayed away from heavily populated and visible areas (Golden, 1992).

During the 1960s, the number of homeless women slowly began to increase, mainly as a result of increased divorce rates and the deinstitutionalization of mental hospitals. Divorce rates began to rise in the 1960s, continuing until the early 1980s which led to an increase in the number of homeless women. When a couple with children divorced, the female usually gained custody and responsibility for the children, creating a financially difficult situation for many women (Timmer, Eitzen \& Talley, 1994). In the late 1970s and 1980s, there were changes in the homeless population that resulted in this group being defined as the "new homeless". The new homeless were much more visible to the public, not as likely as the previous homeless to be employed; more minorities became homeless, and there was an increased number of women composing the homeless population (Glasser, 1994).

In the United States, there was a fifty percent increase in the demand for emergency shelters by families between 1995 and 2000, and this trend seems to be continuing (Weinreb \& Rossi, 1995). In a study by Feltey and Nichols (2002), in-depth interviews were conducted over a twelve-year period with close to 200 women staying in emergency homeless shelters, singlebattered women's shelters, or transitional housing for single-parent families. From data collected on homeless mothers living in shelters with their children or separated from them, there was no one single reason that led to their homelessness situation. A number of factors intersecting over the life course placed women at risk for homelessness in their adult lives. At individual levels, intimate partner violence, low standards of education, instability of intimate relationships, drug and alcohol abuse, lack of social networks with higher levels of conflict, all increase women's 
risk of homelessness (Bassuk, et. al, 1997). On institutional levels, lack of employment, no affordable housing opportunities, limited housing assistance programs, and higher cost of health care led to the homelessness of majority of individuals and families (National Coalition for the Homeless, 2011).

Although some women explained how they moved from the couches of friends and relatives before moving to a homeless shelter, other women narrated how they began their journey from battered women's shelters to homeless shelters. Both shelters treat clients as different with particular needs, regardless of the fact that their services overlap. There are significant parallels between the stories of the women from the two shelters, specifically, the role of intimate partner violence in their lives, leading to their present homelessness situation (Williams, 1998). A study participant shared how she moved from a battered women's shelter to a homeless shelter when her husband started abusing drugs. She said, "I came here (to the homeless shelter) from the battered women's shelter. I went there because of my husband. We have been together ten years. Before he got into drugs, he was the ideal father and husband. But the drugs led him to hurt me... and sell most of the possessions in our house. It took me a long time to figure out what to do" (Mcnamara, 2008, p. 115). Another survivor of intimate partner abuse laments her confusion as to how to handle her relationship while staying with the abusive partner.

\section{Development of Domestic Violence Shelters}

In the early 1970s, domestic violence shelters developed in the U.S. and England. This was in response to the cries of women secluded and confined in abusive relationships. Many survivors appreciating the dangers others like them were facing began opening their homes as place of safety. Other women groups began to purchase and rent small as well as large homes, 
gained non-profit status and started providing shelter services for women and their children struggling with abuse. During this period, there were no laws passed against intimate partner abuse and the man in the relationship stood unquestioned in any incidence of physical abuse between him and his spouse (Olsen, 2007).

The first DV shelter in the U.S., called Transition House, opened in Boston in 1974 and continues to support women struggling in abusive relationships today. Shelters offered women safety and respite from abuse. Traditional shelters were often located in rented houses, and there was easy entry for potential residents (Donnelly, Cook, \& Wilson, 1999). Sullivan \& Gillum (2001) found out that, later shelters often shared facilities with local Young Women Christian Associations (YWCA) or used institutional settings such as motels or deserted orphanages. Shelter staff tirelessly made these settings very comfortable for these women and children. Women in the shelter worked together, sharing household duties such as cooking and cleaning.

Most often, living arrangements were communal and different families shared limited space. Residents were allowed to stay from a few days to a few months. Domestic violence shelter programs are not all similar. However, most share definite commonalties. Most shelter stays commence with a telephone call from a woman who has either just suffered battery or who knows she is in imminent danger of being battered. Every staff member or volunteer who answers the call is trained to evaluate the urgency of the situation, to offer emotional support and understanding, and to decide if the woman has to visit the shelter directly, needs to receive medical attention at a local hospital, or needs to stay in the home of a friend or relative (Sullivan \& Gillum, 2001). It is worth noting that most women choose to enter shelter programs only as a last resort (Shostack 2001). 
Women who suffer intimate partner violence sometimes choose to cope with partner violence using their own internal resources. When women in abusive relationships are in danger and have insufficient protection and support, they are often forced to seek assistance from shelters, among other services. Shelters for battered women usually provide protection and serve as a hiding place. Domestic violence shelters for battered women offer physical protection, and refuge, enrichment programs, support and reinforcement for the woman and her children, and make arrangements for her return to the community, among others. Furthermore, shelters for battered women educate them about other options they have instead of enduring life with an abusive partner (Haj-Yahia \& Cohen, 2009).

According to the residents of domestic violence shelters, the programs they go through are very supportive and effective resources, pertinent to their struggles with abusive partners (Bowker \& Maurer,1985; Sedlak, 1988; Straus, Gelles, \& Steinmetz, 1980; Tutty, Weaver, \& Rothery, 1999). Most programs provide all services at no cost, and they were created to empower and respect women (Ridington, 1977-1978; Schechter, 1982). Shelters have a supportive social atmosphere where women are able to develop healthy relations with one another.

In addition, the battered woman's self-image is bolstered and she is helped to overcome any forms of fear, anxiety, and other reactions that are aroused by her partner's violence. They also offer advocacy services, legal counseling and representation, and mediation between the women and services in the community. Prior to moving into a shelter, mothers had to make the tough decision of either leaving their children with relatives or friends instead of exposing them to shelter living, or take the risk that involves losing custody of their children. It is a usual case that mothers living in shelters are much more likely to be separated from one or more of their 
children than are mothers with public assistance who have not struggled with homelessness (Cowal, Shinn, Weitzman, Stojanovic \& Labay, 2002).

\section{Nature of Shelters}

The needs of children are also catered for in most shelters. Young children who move into shelters with their mothers are enrolled in kindergarten while local school placement is arranged immediately for children who are old enough to be in schools (Tutty et al., 1999). Mothers reported that they and their children were always hurt by the separation even though their aim was to protect their children from homelessness and the experiences of shelter living. On one hand, some mothers lied about staying in shelters to their children with the explanation that they were going away for a little while. Others also were in contact with their children through calls as well as regular visits. More so, this was also emotionally consuming, as one mother described, "It is very hard. I cry almost every evening...Talking to my kids on the phone and they say 'Mommy, I am ready to come home. Please hurry and find a home'” (Averitt, 2003, p. 115).

In other studies, shelters provide a support system for women and their children by affording them a communal living arrangement and a starting point for managing their own affairs. Dobash and Dobash (1987) noted that women and children typically remain in residence for two weeks, during which time they receive an opportunity for counseling, education and training, and for assessment and planning with regard to housing, employment, legal rights, and financial assistance. The shelter experience also gives room for mothers to build strong relationships with their children, who may also be victims of family abuse and emotional trauma due to situations of being witnesses of violence in the home (Hofeller, 1983; Mayhall \& Norgard, 1983). 


\section{Shelter Rules}

Most shelter regulations are similar and these include times a resident can leave the premises, assigned duties, childcare, babysitting, safety rules and measures, rules for contact with her spouse, calling times, living allowance, equipment, and procedures for exiting the shelter (Robert, 1998; Shostack, 2001). In a study by Shostack in 2001, the most common rules among most shelters for battered women were:

(1) Violence is prohibited in any form

(2) No smoking in private rooms (although most shelters have a public area where smoking is permitted)

(3) No alcohol and psychoactive substances are allowed

(4) Every woman is responsible for her personal belongings, and provides clothing for herself and her children

(5) All of the women are required to partake in regular maintenance of the shelter

(6) Mothers living in the shelter with their children are obliged to cater for them when there are no planned provisions (usually in the afternoons)

(7) Women did not have to disclose shelter location to anyone to prevent the abrupt exiting of the shelter

(8) Women who leave the premises for personal reasons must return as early as possible, and in most shelters no later than 11:00 PM

(9) Any woman who disobeys the rules of the shelter will be asked to leave 
Shelter address and telephone numbers are expected to be treated confidential by the women residing there as well as by the staff and any other professionals who are in contact with the facility (Agnew, 1998; Dobash and Dobash, 1992; Robert, 1998; Shostack, 2001). Some authors also mention that most staff of shelters create rules when they are inundated with the disarray of shelter life and never revisit these rules to question them. For instance, Olsen (2016), a former shelter staff worker described how peculiar incidents at the shelter where she worked led to general rules that the staff never reviewed or questioned. As one instance of this pattern, if a resident had something of hers stolen, a rule might be established that all personal possessions get locked up. Other authors do draw a direct linkage between the requirements of funders and the expansion of rules in shelters, noting that demands of funders for more structure were met with the creation of more rules (Chang, 1992; Donnelly, Cook, \& Wilson, 1999).

For instance, requirements about who should receive shelter services led to rules about who should gain admittance into shelters. Regulations requiring evidence of success, as defined through a top-down process, shaped rules concerning what women should be working towards, such as finding stable housing or leaving an abuser, rather than permitting every woman to define for herself what she needed from her shelter stay (Smyth, Goodman, \& Glenn, 2006). Indeed, shelter workers revealed that they faced so much pressure from funders to enforce rules that often was against their feminist beliefs (Chang, 1992; Rudrappa, 2004), as they found themselves "spying on, telling on, and ordering around the very people whom they had come to help" (Holden1997, p.124). Other workers reported experiencing a tension between their aims to empower and support survivors of domestic violence and the need to enforce rules that many of them found infantilizing and humiliating to the residents (Holden, 1997). 
According to Cosgrove and Flynn (2005), a common rule that is enforced in shelters that mothers dislike is the "no spanking" rule. Mothers explained that this rule limits their authority over their children and makes them feel less effective, especially when corporal punishment is a typical route they take as mothers to discipline their children. One of the mothers interviewed by the researchers narrated how whiny and undisciplined her daughter had become because the child knows she is not to be hit regardless of the wrong she does. More so, mothers have felt their power over their own children usurped in times they have tried regulating their children's behavior as staff come in to instruct children differently. Homeless mothers are often fearful because they are aware that they might get into trouble for not being able to control their children (Lindsey, 1998). On the other hand, their actions to keep their children in check can be defined as abusive by the staff. A mother explained how she got her name on a list because she told her son to shut up and stop crying about something. She further explained that a staff person she did not have a harmonious relationship with said she was verbally abusing her son.

Mothers were very concerned about their names being written down for various "unlawful" acts due to the possibility of expulsion. Many homeless shelters give residents' up to three counts when it comes to rule violation. The third warning results in termination or being “exited" from the shelter (Friedman, 2000). For other respondents, actions that would be considered normal in the comfort of one's own home become offenses that can lead to a residents' stay terminated. One mother in a study by Felty and Nichols (2002) narrated she had her name up on two counts. Once for eating in her room and the other for cussing. Hence, she was scared of uttering a word since she had just one more to go. This fear is aggravated by the threat of termination if homeless mothers fail to obey the rules enumerated by shelter staff (Averitt, 2003). 


\section{Coping with Shelter Rules}

According to Glenn (2010), women narrated how they managed to live within shelters in a number of ways. In one category of participants, they explained they had no choice than to follow the given rules, particularly when they remembered that the repercussions of disobeying a rule or speaking up about any rule-related frustrations could lead to their homelessness. Amy described endorsing a warning that she received and disagreed with related to parenting rules. This action she took still hurt her on the inside. Elly spoke about her frustration with curfew rules but she said she adjusted within the confines of the rules. Others expressed similar sentiments: Kim wondered why she needed to sign forms regarding rules, but she resolved to sign especially because it was not her own home (Glenn, 2010).

Ingrid and Helen shared the sentiment of holding back on their words regardless of their opinions because they believed that speaking up will not change anything. In Ingrid's case, she reiterated how expressing her concerns was not worth getting kicked out. In addition, other residents who complained did not have their issues addressed so she decided there was no need to bother. Helen mentioned that their frustrations with the rules came up occasionally. However, staff referred her to tasks she had not yet completed or had not done properly according to staff. She ended up biting her tongue and decided to obey anything staff say to avoid any termination (Glenn, 2010).

\section{Children Living in Shelters}

When children were asked about their experiences in the shelter, they expressed how much they appreciated recreational activities provided by the shelter in the form of tickets to concerts, ball games, and swimming lessons. Children also liked the "no-spanking" policy and mentioned that their mothers could not "whip them" for anything they did wrong (Arrighi, 1997). 
Whereas it is hard to isolate the effects of shelter life from the mainstream consequences of poverty on families living in economically disadvantaged communities, there is evidence that homelessness poses numerous threats to the well-being of children. Particularly, homeless children shelters are at risk in terms of health problems, developmental delays, psychological problems, and educational disadvantages (Rafferty \& Shinn, 1991).

Homeless children are likely to start having issues with their health, before birth. This is due to the fact that a high percentage of pregnant homeless women barely receive prenatal care and they have a higher probability to have low birth-weight babies than housed poor women and women in general. Common health disorders among homeless children, often occurring at twice the rate of the general population, include upper respiratory infections, skin ailments, ear disorders, chronic physical disorders, and gastrointestinal disorders (Rafferty \& Shinn, 1991).

\section{Shelter Residents Account of Experiences}

According to Krishnan \& Hilbert (1998), women take a bold step when they decide to reside in shelters where they have to live communally with strangers, obey likely rigid rules and move into a completely new geographic location to simply flee from an abusive partner. With this in mind, a battered woman is therefore likely to weigh a number of alternative coping options prior to making the decision to enter a shelter. Therefore, it is not amazing that the small body of research considering specific features of women who access the services of domestic violence shelters reveal that these women are among the most vulnerable battered women survivors. They are probably the population of survivors to be financially destitute, homeless, drug addicted, or detached from social networks (Krishnan \& Hilbert, 1998; Schillinger, 1988). More so, this group also report repeated abuse than do survivors who do not seek shelter services (Gondolf \& Fisher, 1988). 
Few researchers have considered women's experiences in shelters, however, existing research portray that many women measure their shelter experiences positively, largely in comparison to other DV-related services (Bowker \& Maurer, 1985; Gordon, 1996; Tutty, Weaver, \& Rothery, 1999). Women also mentioned that as they engaged in therapeutic groups at the shelters, their self-image was enhanced and they became more independent (Haj-Yahia \& Cohen, 2009). In a survey conducted by Garza (2002), respondents reported that they saw much improvement in their self-image, felt empowered and their feelings of depression had diminished because of shelter programs. Regardless of the social, organizational, and physical conditions at shelters, other studies have revealed that battered women residing at shelters have been grateful to these shelters for the opportunity to live in protected spaces and to be able to leave their abusive partners (Agnew, 1998).

Besides these positive impressions, studies have also revealed more ambivalent and critical responses. It has been found that social workers perform certain tasks that generate a sense of disappointment with the care at the shelter. Concomitantly, the women disappoint the social workers in many ways (Eisikovits \& Buchbinder, 2000). It has also been revealed that shelters for battered women generate processes, which inhibit empowerment because of the social and economic gaps between the staff and the women (Davidson \& Jenkins, 1989). Hoff (1990) found that the main complaints expressed by women at shelters focused on the lack of emotional support, as well as on the frequent, unstructured, and ineffective therapeutic groups.

Shelter residents lamented how they lose autonomy and decision-making privileges by staying in a shelter. They no more have the power to decide what needs to be fixed for dinner or even what to watch on television. Moreover, shelters have an "open door policy" that means residents were not allowed to lock their rooms in order to keep their belongings safe (Friedman, 
2000). Again, representatives from funding agencies and members of the community often visit the shelters, exposing families to further feelings of humiliation, as they feel displayed as "the homeless." Hence, the private lives of these residents are no more private and their home becomes public, institutionalized, and out of control for these families (Stark, 1994).

Results from a study by Haj-Yahia and Cohen (2009) on the lived experiences of battered women staying in shelters revealed the following; for one resident, Ma'ayan, the shelter facilitated growth and development. It opened new doors for her and provided stimulation and opportunities. The stringent rules and prohibitions were marginal and insignificant for her, and she did not mention any problems related to communal life, invasion of privacy, difficulty with exposure, or intensity of relationships in the shelter. For Ma'ayan the shelter was a panacea for her problems, and she believed that it provided her with solutions in many spheres of life, regardless of its drawbacks. Similarly, Tamar described life at the shelter as highly encouraging. She mentioned the familial atmosphere, the feelings of intimacy, warmth, security, love, and acceptance, as well as the freedom. Tamar described the place as giving her strength to cope and persevere, and emphasized that the shelter set no boundaries, restrictions, or prohibitions. She did not feel closed off, and felt that the duties were clear and understandable.

Tamar also narrated how her shelter experience has been one of self-discovery as well as development of her liberty and independence. For her, staff and other women gave her a sense of security, offered a form of protection, and treated her with dignity. She did not feel restricted nor obliged to do anything she did not personally want to do. In addition, she was assisted to meet her emotional and financial needs through supportive discussions and encouraging words. Tamar was 63years old and in her opinion, she had just started defining her own wishes and desires and she emphasizes her readiness to manage on her own. 
Another woman, Suha, agreed with Tamar and appeared to be taking advantage of the temporary break from her partner to work on herself and develop her insights, to gather strength, and to make decisions (Haj-Yahia and Cohen, 2009). In this same study, Lilia, another resident was ambivalent about the shelter, and described its advantages as well as its disadvantages. The first advantage she described was the atmosphere of trust, which surprised and impressed her. Afterwards she mentioned the physical and emotional security that the shelter provides. In addition, the rules and duties at the shelter seemed natural and clear to her. However, despite these advantages, she complained about crowded conditions, noise, and lack of privacy, lack of financial resources, a temporary atmosphere, and restrictions related to employment opportunities. Inbal also expressed ambivalence. Her main complaints related to the rigid enforcement of rules about maintaining relationships with other men, the prohibition against staying out late, and the forced isolation from the outside world. Furthermore, Inbal mentioned the lack of an arrangement for her children in the afternoons and the lack of guidance in parenting (Haj-Yahia and Cohen, 2009).

Hanin on the other hand explained she did not really like the staff members. She felt there was a gap, inequality, distance and even some hostility and tension. She explained she found it difficult to appreciate how they controlled her. She believed residents needed to be managed and not controlled. In addition, she described her shelter experience as one that brings a boarding house feeling and emphasized that the staff discriminated amongst women; some women were at the top while others were at the bottom. For Aya, she draws a comparison between her shelter experiences with her childhood experience. She mentioned how cleanliness inspections at the shelter reminded her of how her mother rigidly inspected her room as a child. More so, she lamented her privacy was also invaded anytime the daytime coordinator went into 
rooms to point out to residents what was wrong and how to put things right. Another memory of her mum. She shared a childhood rape experience and reiterated that any attempt of shelter staff to "put things right" in her life is an invasion of privacy (Haj-Yahia and Cohen, 2009).

\section{Theoretical Framework}

According to Rodriguez-Menes and Safranoff (2012), five main theoretical streams explain domestic violence against women. Three of them, sexism, family violence and dependency theories, consider characteristics that associate family units as predictors of violence while the other two, exchange and status inconsistency theories, focus on relational aspects of the couple. Sexism takes a 'cultural' approach; family violence belongs more to the 'economic' pole. Dependency, exchange and status inconsistency theories include both cultural and economic elements. Along with sexism, the three highlight the role of patriarchy in promoting violence against women, even though each conceptualizes it differently. For all five theories, the factors considered as being associated with violence are treated as risk factors increasing the probability of observing it. Women's lives are too complex to be completely explained by any theoretical model. These researchers believe that any factors neglected would cancel each other, having no systematic effect on violence (Rodriguez-Menes and Safranoff, 2012).

The sexism perspective can be traced back to Dobash and Dobash's (1979) early feminist work on wife beating. Like many feminists, sexism scholars argue that the dominant reason explaining women's violence in intimate relations is uneven relations of power between men and women within patriarchal societies (Dobash and Dobash, 1979;Yllo, 1993).Violence is the most extreme expression of patriarchy, understood in this approach as a sexist cultural system of domination suppressing women to men: directly, through cultural norms of deference and obedience backed in some cases by the use of force; or indirectly, by shaping women's 
opportunities and constraints in basic institutions such as the family and work that reinforce women's subordination (Kim and Sung, 2000).

Anderson (1997) states that feminist scholars employ single variable analyses that emphasizes patriarchy and ignore the impact of factors such as income, unemployment and age. For these critics' feminists' highlighting patriarchy is one-dimensional and simplistic (Dutton, 2006; Gelles, 1985).The family violence perspective argues that patriarchy is just one among a myriad of factors related to inequality structures creating conditions conducive to violence (Gelles, 1993;Straus et al., 1980).This 'socio-economic' view criticizes sexism scholars' omission of factors such as social class that, independently or together with gender, predict violence in the family (Kasturirangan et al., 2004; Lee, 2000). These factors specify, instead of questioning the quasi-necessary role of sexism in violence, this view is not distinct from the sexism perspective (Rodriguez-Menes and Safranoff, 2012).

Exchange theory (Gelles, 1983) is also part of a broader 'bargaining power' perspective. It focuses on women's resources relative to men's. In its radical form, it is indifferent to gender and analyses how resources facilitate the exertion of power by whoever has more. According to Gelles (1983), males exert violence on women 'because they can'. Recent views that focus on women's violence on men belong to this symmetric approach (Straus, 2006). Exchange theory considers women's inferiority to be 'quasi-necessary' for suffering violence from the dominating partner, although perhaps not sufficient, as other factors may specify the conditions that facilitate it. When exchange theory is combined with patriarchy, women's subordination appears as its most basic element and the main exogenous cause of violence (Johnson, 1995). O'Brien (1971), Rodman (1972) and Gelles (1974) can trace the status inconsistency perspective back to work on how differences in occupational and educational attainment favoring women in intimate relations 
disrupt traditional patriarchal roles leading to violence on women. Women's complete resources deter violence, but when they exceed a partner's they trigger a man's violent reaction to compensate for his status loss. 


\section{CHAPTER III: METHODS}

This chapter covers the various methods and techniques that the researcher employed in the study. It considers the sample, recruitment of participants, instrumentation and analysis of data. The research was exploratory and sought to assess the subjective experiences of female survivors of intimate partner violence living in regular shelters.

\section{Sample}

The researcher interviewed four (4) female residents of a homeless shelter who had suffered various forms of abuse from their partners. The study sought to identify their subjective experiences while staying at the shelter and the forms of support that were made available to them during their stay. Criteria for participation included being victims of partner violence, residents in a shelter, no record of mental illness, satisfactory verbal ability, and willingness to be interviewed. Participation was strictly voluntary, and participants had the opportunity to exit at any point in time. The sampling was purposive and theoretical. Participants were selected based on their willingness to participate (Sabar Ben-Yehoshua, 1990). This non-probability sample technique allowed the researcher to focus on specific characteristics of the population that was relevant to the study (Glenn, 2010).

Moreover, since the study participants were female residents of the homeless shelter that were survivors of intimate partner violence, it was pertinent to employ purposive sampling technique for the selection of the study participants. Female residents ranged from the 20's to the 30's. No participant was more than the age of 40 years. All the women were single and had children. Out of the four, two of them had young children with them at the shelter, while the other two had older children who did not live with them at the shelter. They were all white by 
race, and as residents, they arrived at the shelter from different states in the U.S. Two of the participants were jobless while the other two participants had part-time jobs at the time of the data collection. The two with part-time jobs worked in informal settings to support themselves (Haj-Yahia and Cohen, 2009). All participants had more than 15 years of formal education. Two of them had high school education while the other two at the time of the interview had some College education. In terms of length of stay at the shelter, participants had spent a range of 1 month to 12 months at the shelter, averaging 5.5 months. It is noteworthy that one of the participants had been in and out of shelters for five years, at the time of the interview. For the purpose of confidentiality, all women were assigned pseudonyms in this study.

The interviewer asked the participants to identify their race in order to understand whether or not their shelter experiences are connected to their unique demographic characteristics in any way. Open-ended questions which participants responded to are outlined in the interview guide (Appendix A). Prior to the data collection, the researcher received approval from the Institutional Review Board (IRB) at Illinois State University on January 5, 2018. IRB protocol identifier for the study is 1129867-2.

\section{Recruitment of Participants}

The researcher first held an informational session for female residents with the support of a staff member at the shelter in Bloomington-Normal, Illinois. Out of a total number of approximately seven prospective participants who were invited, one female resident was in attendance. The staff member explained the potential participants might be uncomfortable to share their lives with a stranger. The researcher shared the purpose of the study through an oral presentation and also handed out a poster (Appendix B) with information on the study. The poster was hung on the women's floor of the shelter. The researcher then turned in sign-up sheets 
to case managers, per the permission of the director of the shelter. These were dated from February through March 2018. Female residents who decided to participate in the study chose feasible dates in order to speak with the researcher.

The shelter visited by the researcher was of particular relevance to the study. This is because it is a regular shelter where women who are homeless for various reasons which includes suffering abuse in the hands of an intimate partner sought refuge. Thus, residents were informed about the study as their specific experiences as women who had gone through intimate partner abuse was purposive; subjective and related to the study. The director of the shelter informed the researcher via email, any time a potential participant signed-up. The details of the study were outlined to all potential participants before the interview process. Every individual also had the opportunity to read a copy of the voluntary consent form for face-to-face interviews, as well as the interview guide before they agreed to participate. Interviews were held in a living room or the chapel, as assigned by a case manager, on the interview day for the privacy and comfort of the respondents. In addition, all interviewees were required to endorse an informed consent form before the interview began. They were also required to endorse a form that stated whether they consented or did not consent to an audio recording of the interview (Appendices C \& D). Participants were also notified, based on (Appendix E), of the fact that they were allowed to withdraw participation at any point in time (Appendix E), and were at liberty to decide whether or not they permitted the researcher to use any data collected. Table one (1) below is a summary of participants' demographic characteristics and highlights of their experiences under specific themes. 


\section{Table 1: Interview Participants}

\begin{tabular}{lclll} 
Participant Pseudonym & Age & Race & Marital Status & Occupation \\
\hline (1) Albie & 34 & White & Divorced & Unemployed \\
(2) Priscilla & 37 & White & Single & Unemployed \\
(3) Geraldine & 34 & White & Single & Employed (Part-time) \\
(4) Jocelyn & 24 & White & Single & Employed (Part-time)
\end{tabular}

Level of Education

(1) Associate Degree

(2) K-12

(3) Some College

(4) GED (High School)
Shelter Length of Stay

4months

2months

5years

3years

\section{Participant Experiences}

\section{Opinion of Shelters}

Priscilla: "Full of crap. Giggles! That's how I feel today".

Geraldine: " "...Shelters can get chaotic and messy."

Albie: $\quad$ "I had never really thought about it much before I realized I'm gonna probably figure something out. For my children's sake and their well-being, we have to go somewhere with more opportunities. A lot of people, when they think of homeless, they think we are bad people but it's not how I have seen it at all".

Jocelyn: "Shelters are just there to help you to make it... It's a community that looks out for one other." 


\section{Improvements}

Priscilla: "They look at you like everybody. But we are different. They shouldn't treat us the same. Oh, she's not gonna do this, she's not gonna do that."

Geraldine: "I would like to see support groups for kids they are going through stuff too."

Albie: "Maybe having a schedule that you have to do a certain amount of work service hours and they can give you a ride to an appointment or something. Honestly, the bus passes probably will be the best."

Jocelyn: "It's a good place I like it here. I don't think anything should be improved."

\section{Instrumentation}

In order to obtain detailed experiences of the victims of domestic violence in the participants' own words, semi-structured interviews were conducted on a one-on-one basis with each participant. Semi-structured interviews are neither highly structured nor unstructured. This creates a comfortable conversation between the researcher and the respondents (Glenn, 2010). Merriam (1998) supports the flexibility and usefulness of semi-structured interviews by arguing that this interviewing format "either all the questions are more flexibly worded, or the interview is a mix of more and less structured questions" (p. 74). Every participant was allowed to freely share her experiences without any restrictions. However, an interview guide (Appendix A) was used to ensure that all major themes had been covered.

The researcher began each interview with the collection of demographic data as outlined in the guide. This included gender, age, race, marital status, occupation and level of education. The participants self-reported their length of stay in the shelter. After the interviewer had taken into account all demographic data, interviewees were asked to describe their experiences while staying in the shelter. Their narration covered both positive and negative experiences right from the first day at the shelter as well as any previous shelter experience. This began the interview on a very general note and both the interviewer and interviewees were comfortable enough to interact throughout the discussion. Further, participants were asked to talk about the forms of 
support they received from the shelter. Forms of support could be physical, emotional or even psychological. This discussion also included participants explaining what form(s) of support was most relevant to them or has been most relevant to them throughout their stay. This enabled the interviewer to know if the specific needs of participants had been met by shelter services.

Following this, the participants also talked about the relationships they had built during their stay. These discussions focused around those they considered as neighbors, and others who were sitting partners during meals. Participants also shared how they have bonded with other residents, staff and volunteers. The narratives allowed the researcher to know the meaning these women put into building relationships and how relevant the existent or nonexistent relationships have been towards a successful or unsuccessful stay at the shelter. Moreover, participants were also asked to discuss how living in the shelter has impacted their lives in totality. Mothers were asked whether they lived with their children at the shelter and how in their opinion, shelter living has influenced their children's lives. The researcher and participants further discussed relationships amongst children living in shelters and the availability of schools to these children through services offered by the shelter.

In addition, participants also discussed how their shelter living experiences have impacted extended family life. This highlighted the various ways the separation brought by shelter living affected residents' immediate and extended family members. Next, the interviewees were asked about any learning experiences that play out even when they are outside the walls of the shelter. This account provided the interviewer and interviewees' information about how much of the learning experiences from the shelter received by interviewees had become part and parcel of them and had even been useful outside the confines of the shelter. This information helped the researcher and participants to better understand some rules and 
regulations that had been put in place by shelter staff and the consequences these rules have for shelter residents. In addition, participants were asked to expatiate on how similar or different their living conditions at the shelter are from their original residence. This discussion undoubtedly led to information that revealed whether or not participants had friends who share similar or different opinions. Information from this account also highlighted the common and uncommon views that interviewees had about how much their shelter conditions differ from their original residence as well as how much similarities they find in their conditions at the shelter in comparison with conditions at their original residence and/or previous shelter residence.

Furthermore, participants were asked to suggest ways in which their experiences at the shelter could be improved. This account could lead to information for service providers on how best to improve the experiences of shelter residents based on the perceptions of shelter residents, on how they as residents could best be served. Finally, participants were asked about the perceptions they had about shelters prior to their entry and how these perceptions have changed over time while living in a shelter. More so, this information led to a discussion on whether or not their prior perceptions about shelters affected their stay in any way. These subjective opinions of the participants were very essential particularly for the purpose of this research which sought to fill the gap in existing literature that barely considers the individual perceptions of female survivors of intimate partner violence as they reside in shelters.

\section{Analysis}

Participants' permission was sought, and the researcher audio recorded all interviews, for easy reference to information and for the purposes of analyzing the data. Additionally, recording interviews meant that the researcher was not required to take notes during the interviews. Taking notes can make the researcher leave out relevant information due to the volume of details that 
may come up during the discussion. The researcher penned down general impressions about the interviews before transcriptions of every interview by the researcher.

The recordings were transcribed verbatim. Following transcription, the researcher listened to each recording again while reading along with the transcripts to ensure accuracy. After verification, the recordings were transcribed accurately and the researcher conducted a thematic content analysis of the data. More so, a coding key was created with the questions per participants' responses. The data collected were then categorized under different codes that clearly described the themes of the various questions as well as sub-themes that emerged from the data. Quotations from participants' responses were used to highlight their experiences at the shelter and to generate possible ways their subjective experiences could be improved. All four interviews averaged 44 minutes, with ranges from 30 minutes to 60 minutes. 


\section{CHAPTER IV: RESULTS}

The subjective experiences of women who had survived intimate partner violence and staying at the shelter was obtained by their responses to questions, as portrayed on the interview guide (Appendix A). Codes were created with the themes that emerged from the data and this led to the development of eight main categories with sub-categories, which took into consideration further details of participants' experiences. The researcher also considered themes that could be merged. Such themes were merged with appropriate categories. In paragraphs below, all main codes and sub codes will be expatiated with relevant quotes from the data. The main categories of the codes are: 1) Previous Shelter Experience; 2) Current shelter experience; 3) Forms of support; 4) Relationships built during shelter stay; 5) Impact of shelter living on family life; 6) Learning experiences; 7) Suggestions on improvements; 8) Opinion of shelters prior to stay. All main categories had sub-categories with the exception of categories (5), (6) and (7).

\section{Previous Shelter Experience}

In this category, participants shared their encounters at previous shelters, the reasons they decided to be at those shelters and what differences and/or similarities they gleaned from their previous encounters. Two of the participants' reiterated how helpful their previous shelter stays were in assisting them, while they went through very traumatic times. Apart from a place to stay, they talked about strategies the shelters put in place to make lives better for them. In addition, their responses highlighted the varied reasons they ended up in shelters, and the conscious and unconscious roles played by family members as well as ex-lovers to their living in multiple shelters. One participant said,

Albie: $\quad$ Mainly, the reason why I was there is the most disconcerting part about it. They were very helpful to me. Even though I had an apartment, I didn't feel safe at my 
apartment. And I was going through a messy divorce. There was a lot of abuse in the marriage, and he will randomly show up in my house so I decided to move into an abused women's shelter, until he went to Iraq with the military.

It was apparent during the interview that Albie was more troubled about the abusive situation she was experiencing at the time and spent very few hours of her day at the shelter unlike other residents. She was grateful to be assured of protection from her abuser by the stringent security measures enforced by the shelter. She continued when asked of any differences in shelter stays by stating that this encounter was different because she only needed a safe place to lay her head in the past. In her own words:

Albie: $\quad$ Oh yeah, there were differences. Because at the time, I had family and I had a job so they basically just provided a safe place where I can go to sleep and not worry about waking up with a gun on my face! Giggles. I worked in the evenings so I didn't feel like there were so much restrictions on me. It was just a helpful thing that was offered me. At the time I had family and I had a job. I worked in the evening ...I will take my boys to my dad. My dad used to babysit for me, so I go to work and then later pick them up and go back to the shelter to sleep.

For Jocelyn, who had been to three previous shelters, she explained the shelter provided a home for her. She shared with the researcher how she moved from one shelter to the other due to multiple domestic violent relationships. In addition, she emphasized how family members were apathetic towards her basic needs throughout her life's journey.

Joycelyn: Well, when I was in [name of state], when I moved out there, I was in a really bad relationship; domestic violence. So I ended up becoming homeless and I moved to a shelter there. And I'm spiritual so the spiritual part is gonna tie in this too. I can't tell my story by taking God out of it. My dad was very abusive verbally, so I moved out of there (parents' home) when I was 18 and I said I just want to be on my own. I said I didn't want to have anything with him. From another bad relationship, I ended up in a homeless shelter here at (name of another town). 
Life as a child had been traumatic for her and she emphasized how she struggled relating with siblings especially because her step dad did not allow her. Jocelyn went on to share her experiences in abusive relationships which consequently led her into other shelters.

Joycelyn: After 6 months and gone into a bad relationship again, I ended up in a shelter. It was after I left the girls' house. They threw my stuff out so I slept on the floor. Before I ended up at the shelter, God said, be patient and just rest your mind. Because I was looking for jobs and what not. I have been to different shelters in [name of previous state]. With the domestic violence shelter, it was awesome.

Her experiences with domestic abuse was initially physical. Hence, she was not sure she had faced mental abuse until she ended up in another shelter.

Joycelyn: At first, I didn't consider it physical abuse because it was mental abuse. The domestic shelter, they helped me and I ended up getting three other jobs. A counselor allowed me to talk to myself and that was helpful.

She received different forms of assistance from the previous shelters due to her several encounters with abusive men. She continued to share with the researcher, how through prayer, God led her to speak with Christians who offered her accommodation free. Although she spent a couple of months staying with friends, Jocelyn highlights how shelters took into consideration her peculiar needs as a survivor, looking beyond her physical need of a safe place to stay. In Jocelyn's case, she was not so comfortable with staying in a new state, which she explained was "outside her comfort zone and had to live with people who did not look like her." She believed life out there was "a whole lot for her to deal with."

Geraldine on the other hand had been in and out of shelters for the past five years. She explained how a previous cordial relationship with her case manager helped her feel more welcomed in the shelter. She said,

Geraldine: Um, it's probably one of the better experiences I've had. The person I had 
as a case manager, I had known her before and she even started working here so that kind of made it more comfortable. Um...I generally don't have any issues with the staff, I'm trying not to have any issues with the residents. It's kind of a touch and no deal. Hahaha!

She explained that residents who obeyed the instructions of shelter staff and did not get into trouble with other residents were likely to enjoy a peaceful shelter atmosphere than those who had issues while relating with staff and other shelter residents.

Geraldine: I've been here with kids. I don't have any kids here with me this time. Which even helps a little bit because it's just as traumatic for the kids as it is for us to go through being in the shelter. My previous experiences have been mostly here and at a domestic violence shelter in town. With the relationship with my youngest daughter's dad, he was and still is very abusive, controlling. We are obviously not together. But he has custody of our daughter right now, because I'm in a homeless shelter. And I only have a little bit of exposure to her, one day a week for a couple of hours.

She narrated how her previous shelter experiences were with her newborn baby and a three-year-old child. In her opinion, the shelter experience was less stressful for children when they are younger but gets overwhelming for children as well, in cases where they are teens and much older. They wonder why they no more have their previous homes and do not understand why they have to live with others and share crowded spaces with them. Even though she did not want to have her older children staying with her at the shelter, she was more upset about the separation her shelter stay had brought between her and her children, as well as the many challenges she faced from her ex-lover.

Geraldine: And he [ex-lover] tries to control and dictate what can and can't happen during those visits and he thinks he has the authority to do what he wants but I have to obey his rules. He thinks all my exposure to her, needs to be supervised and there's no evidence to support that theory at all. It's been very hard. I know this is a safe place for children but it's not ideal. Again, it's just stressful for them if not more so, than it is for us. 
Geraldine went on to share a traumatic experience she had due to an incident that happened at the shelter. She did explain the incident was not the fault of anyone but rather her background of abuse and natural consequence of her situation. This is how she put it,

Geraldine: Um...actually last two times was pretty traumatic. Um...not because of anything that somebody did per se here... The last time I tried to stay, I had just come out of a psychiatric hospital and so I was mentally kind of all over the place and really wasn't able to concentrate very well so dealing with recovery from a psychiatric facility that I had never done before. Um... and somebody had a dry birth in one of the bathrooms upstairs and tried to terminate her pregnancy herself after giving birth to the baby, she tried to drown the infant in the toilet. And it was unsuccessful. But the screams were horrific and it was very traumatic. I suffer from PTSD for those kind of instances and others.

She also shared with the researcher a horrible experience she had while a resident at a previous shelter. She emphasized the nonchalant attitude of the staff as well as the police at the time towards an abusive situation. It was obvious Geraldine had lost hope in law enforcement and believed the system was broken even though majority of people might fail to notice.

Geraldine: And a couple days before Christmas, I was assaulted at [name of shelter] and the director never did anything. She denied it happened, and the police said if staff wouldn't do anything about it, we are not going to do anything either. It didn't get very far, um...I didn't allow that or anything, um...I fought back. It didn't get very far... but just the trauma of it and having been in that position before, several times, in my life. It's not something I'm gonna continue to tell everybody....and to say...The director is just Gosh, awful!

The last participant, Priscilla however had no previous shelter encounters. It was her first shelter experience at the time of the interview. It is worth noting that, it was needful to gather information on participants' previous shelter encounters in order to know how their backgrounds have influenced their shelter experiences holistically. 


\section{Current Shelter Experience}

With this category, participants were asked to share both positive and negative experiences, so long as they were willing. The researcher also inquired from participants if they felt safe. This main category had a sub-category especially because of how significantly it is related to the main theme of this study. This is what Priscilla had to say,

Priscilla: $\quad$ It's pressure. A mixture of everything. It's a lot of pressure. From getting jobs, work service. Like leaving the streets and coming in here.

It was Priscilla's first two months at the shelter and the researcher noted from her account that she had been overwhelmed and frustrated by the new experience of having to obey shelter rules. The shift from living on the streets to shelter living is one that Priscilla had not anticipated to be stressful. She shared her dissatisfaction with how resources like bus passes and laundry services were managed.

Priscilla: $\quad$ They need to upgrade the rules and change them up a little bit. And start being more lenient. And more you know, I mean, they just need to change the rules up. Because, it is blowing me. It is crazy. It is a lot of pressure on one person to fulfil everything that they want to be fulfilled. They want you to go out of your way to make things happen. I understand that but at least meet me half-way. That's all I ask. At least meet me half way. I am trying to do what I can for you to hold my but down. If you don't kiss their but, they are gonna kick you out.

Albie expressed how she had come to appreciate the resources the shelter had made available to her and lamented how bad her experiences had been on other occasions. She was particularly unhappy about how some of the staff members treated residents with disdain. Nevertheless, Albie was satisfied with the opportunity she had as a survivor to interact with other survivors on a daily basis. She narrated,

Albie: $\quad$ I have learned about a few resources to use. Like Path has helped me get my birth certificate. There has been a chance to speak with others in similar situations and we can speak and talk about how we are all trying to manage and support each 
other. More of support groups. Most of the staff are friendly but it is hard to be in a situation like this. It doesn't take long to have the rug pulled from under you and you have to find yourself in a place like this. And you just wanna think, "I don't think you will even be here if you went through half of the things that I have."

She went on to lament how through interactions she had with staff members, she knew without doubt that, she was disrespected by some members of staff because she was a shelter resident. She highlighted how difficult it was for a person to not become the nametag he or she receives from staff. Albie is another respondent who complained about the numerous rules one had to obey upon deciding to stay at a shelter. She was not happy about the limited time they had as residents to hang out at certain locations and at certain times in the shelter. She also believed shelter residents had very limited freedom and shelter staff were inconsistent with keeping the several rules spelled out to residents.

Albie: $\quad$ It is very easy to judge people when you only see a portion of what they are experiencing. So that makes it hard when people look down on you and treat you like you're a piece of garbage or like they're better than you. And sometimes it's hard to not feel like that! Their body language, their tone and general demeanor of how they interact with you as opposed to how they interact with their co-workers makes you know.

She was displeased about the treatment they received from shelter staff as residents. The researcher could tell from Albie's account that she had a negative perception with regards to the staff-client relationship at the shelter.

Albie: $\quad$ A lot of us here most of the times feel like we're in a jail. We are locked in certain areas, from certain areas, and the people that enforce the rules are often very rude about it sometimes. For instance, with the times that we're allowed to be in there to eat and have our snacks, that's one of the only places we have to socialize, it's very cold outside right now. So we can't just hangout outside and talk with each other. So whenever we do sit down for coffee we have someone come over and be like, you have 2 minutes, you have to go! And it's like oh, we just sat down five minutes ago. 
From Albie's account, it was apparent she felt shelters deprived residents of their freedoms in terms of shared spaces and the opportunity to interact with one another. She had been troubled by the limited time they always have to socialize and found shelter staffs' approach to rule management impolite on some occasions. Priscilla also complained there were many rules for residents to follow. She believed shelter staff were not genuine with residents and asserted they didn't really care.

Priscilla: $\quad$ They laugh with you but at your back, they are laughing at you. It's like the penitentiary. It does, feels like jail. Behind the scene, you are going through a lot. It's bad.

Jocelyn and Geraldine expressed contentment when they were asked about their current shelter experiences. Jocelyn preferred the community in which the current shelter was located as compared to the locations of the previous shelters she had lived.

Jocelyn: It's alright, I'm blessed to be here. Staff are very nice and supportive. They serve good meals. As long as you do what you are told to do, they leave you alone. It's a supportive community here.

Geraldine reiterates the supportive nature of staff members and their preparedness to address her concerns. She clearly revealed she has a cordial relationship with staff as well as other residents.

Geraldine: I like it here because they will talk with you and when you have any issues or grievances, they will want to hear you out and see if they can compromise or something whereas with other shelters, they don't do that at all.

One of the participants, Geraldine had narrated several positive experiences she had at the current shelter, compared to negative ones she had at previous shelters. However, she asserted that staff were not competent when it came to handling issues of mental health amongst some of 
the residents. In addition, she believed management did not pay particular attention to survivors of abuse even though some residents were from abusive backgrounds.

Geraldine: With [name of shelter], it's a battered women's shelter so this shelter doesn't focus on that necessarily here. I don't know whether that is really good or bad, it's good that they know that there are resources in terms of helping people out to other facilities. But if you have a mental health crisis, they don't seem to handle that very well. They rather ship you out to the hospital or [mental health facility] or to whatever is available at the time.

On the follow-up question regarding whether or not participants felt safe at the shelter, the researcher identified that participants had varied opinions on what it meant to be safe at any point in time in their lives. Even though they all admitted they felt safe, they opined their individual perceptions on different levels. Albie explained how she had gotten accustomed to ensuring her own safety especially because of her past abusive relationship.

Albie: $\quad$ Sure, I feel safety is something that you either feel it everywhere or you either feel it nowhere. Personally. Did that make sense to you? Giggles. So, when I lived at the shelter before, when I was going through the divorce, I was going through so much traumatic things. All at once. In a short period of time. I got married, he got very abusive, very quickly. I had a car accident and was severely injured and the abuse got worse... I never knew when he was gonna show up, I never knew when he will just appear in a car behind me and try to run me off the road, which he did a couple of times...So then I didn't feel safe anywhere. Going to that shelter and being locked behind 5 doors, and knowing he didn't know where I was, that was the only thing that kept me sane. Even in dangerous situations, I don't feel unsafe. Because I know that if you are aware of the danger, you can watch them and know how to react.

For Jocelyn, she felt safe and was grateful to have a comfortable room to herself during her shelter stay. She also shared how convenient it has been for her to get many tasks completed once she had a temporary place to call home. She reiterated the support she received from shelter staff at any point in time.

Jocelyn: $\quad$ Yes, (child's name) and I have a room to ourselves. And at a place where residents are supported and encouraged to be their best. 
She liked the services the shelter provided to residents and believed shelter staff contributed greatly to residents' path to becoming independent.

Jocelyn: I was able to accomplish a lot of stuff as far as bus passes. They gave us a voucher for our clothes and of course, I had to get day care going for [child's name] and our birth certificates.

Priscilla on the other hand appreciated having a place to stay instead of living on the streets while Geraldine expressed how one is protected, loved and have her concerns addressed while staying at the shelter. She believed her current shelter was safe and much more organized than previous shelters she had stayed. She also shared with the researcher how her current shelter had several staff members available for residents' easy access for any form of assistance.

Geraldine: This is a safe and controlled environment where [name of another shelter], it's much more chaotic where people try to enforce the rules, but they are not consistently enforced and the staff members are always changing, and the director doesn't really want to get involved with the real issues at the shelter. I don't feel like it's working for that facility. But we also have more staff over here and we also can have a wider spread of options. I like that they have classes for you to regain your independence and work towards becoming better to get back in the world.

\section{Forms of Support}

Participants were also asked to share any forms of support that had been made available to them in the shelter. Further, the researcher inquired from participants, which form of support, has been very relevant to them, in order to know what factors had contributed most to make their stay possible. All four participants mentioned the several resources like bus passes, which have been made available to assist them as they work towards becoming independent. More so, they emphasized how much they appreciated the emotional support that came from other shelter residents. Regarding forms of support that has been most relevant to them, one participant, Jocelyn, 
talked about spiritual support, which has been very relevant to her stay while the other two, Geraldine and Albie discussed the physical and emotional forms of support they received at the shelter.

Jocelyn: $\quad$ Spiritual...It's God! My abusive stepdad was a pastor. So I was confused. It took me about 7 years to realize it wasn't me. When you preach God and you are abusive, it sends a confusing message. To others, he played saint but was very abusive at home.

It is worth noting that Priscilla was not certain about the specific form of support she received at the time of the interview.

Priscilla: $\quad$ I really feel nothing. No support really. Maybe emotional.

Geraldine and Albie explained how meaningful the individual relationships they have formed with other residents have been helpful to them. Geraldine went on to express how impressed she was with the shelter's level of spiritual training and upliftment on a regular basis. Her experiences portrayed how survivors place a lot of importance on the need to be treated well as residents, regardless of their homeless situation and the struggle towards independence. She also believed the various ways of communicating with her case manager made communication possible at all times even when her case manager was out of the office.

Geraldine: I like that they provide spiritual support and encouragement. That's something that I try to utilize as much as I can. So I try to go to as many of the classes. They have devotions, prayer time every morning, Monday through Friday and then the second Sunday of the month; they'll have it in the afternoon and on the Sunday as well. Um... and I think that really helps kind of not just reiterating their main purpose which is to help others through God's will and purpose but also to let people know that there's hope. You're not as down as you could go. Giggles! 
She appreciated the shelter focused on the spiritual development of residents. One can conclude she finds a reason to keep going regardless of the crisis in her life. The current shelter stay has been a reliable source of hope compared to previous shelter stays.

Geraldine: Like I said before, I get a lot of support from my case manager. I know I can always leave her a note at the front desk if I'm not able to see her or meet with her and I'm pretty trusting that it will get to her.

The staff members were always available to meet the needs of Geraldine. One realizes she had gotten accustomed to the relationships that existed amongst shelter members. This could be due to the number of years she had stayed in and out of shelters.

Albie: The individual relationships that we have formed have been helpful. No personal relationships with staff.

Participants also highlighted support in the form of resources from staff members but clearly reiterated that they did not see staff as friends to simply share every aspect of their lives with them. One of the participants, Albie also felt mothers with children had stringent supervision and shelter staff were not positive they could offer children proper parenting. In addition, two of the survivors complained about the scarcity of some of the resources and explained it made getting around more difficult if one did not have enough bus passes and any saved money to use on transportation. It is worth mentioning that some of the survivors reiterated how their search for jobs and the need to be at several interviews would be possible if shelters intentionally met their need for transportation with adequate bus passes or created a system where they offer their services to accomplish shelter tasks and receive bus passes to redeem the time spent.

Albie: $\quad$ My case manager is nice but I don't feel like I have the ability to just talk to her about whatever. Being in a place here with a child, it's not easy and it's hard to not feel like you are constantly being watched and people are waiting for you to mess up. 
She explained life at the shelter was rough especially with a child. This made getting around cumbersome. Shelter staff were also concerned about how mothers nurtured their children during their stay.

Priscilla: A lot of us don't have jobs, A lot of us don't have income. We want to get up to make things happen and we need that extra step to make things happen.

She lamented about how she had given up on job searches and could barely afford transportation to job interviews. Her responses clearly showed she had some regrets when it came to how shelter management responds to residents' need for bus passes.

Albie: $\quad$ I find that most people that are here, all of our situations are different but we are all here because we don't have support. And there's no fall back. Like my car broke, and I lost my job and there's no way to get help when these things happen.

It is worth noting residents felt helpless about some of the challenges they faced. Their responses indicate having a stable source of income would bring a lot of relief as they deal with problems that one can only resolve with money.

Priscilla: $\quad$ A lot of us don't have jobs, a lot of us don't have income. You get a bus pass for a day but you need like 30 days. Jobs are far out. You need to show that you are interested and ready to work. They want what they want, and we know what we want. [Name of Agency] runs out of bus passes. I don't wanna waste interviewers' time. But it's just a waste of your time. Everything is not in walking distance. Jobs are far out. It's very frustrating here. It's what it is.

For Priscilla, she appeared burdened about her stay at the shelter. One could tell she had expectations of shelter living although it was her first shelter experience. She believed shelter management had significant roles to play to make the stay of residents comfortable.

Albie: $\quad$ It is difficult to save money when you have basically nothing. I went to a job interview last week. Because I don't have a running vehicle...they had nothing in town for me. They said if I had a van running, they could have a job at a factory out of town I can do. It will be very helpful if we receive bus passes as homeless people. If they say to us, here, have a bus pass so you can try to get something 
figured out. If I didn't have to go and borrow money from people every time I want to go somewhere that is more than walking distance, it will be a lot easier to get out every day.

\section{Relationships Built During Shelter Stay}

In this category, participants discussed the relationships they have formed during their stay.

They further explained friendships that have come about as a result of engaging in activities with other shelter residents. It was apparent that participants simply had a staff-client relationship with staff and not necessarily, any form of friendships.

Albie: $\quad$ There has been a chance to speak with others in similar situations and we can speak and talk about how we are all trying to manage and support each other. So that's the good aspect. Staff...It's hard when people look down on you and treat you like they're better than you. And you just wanna think, "I don't think you will even be here if you went through half of the things that I have. So that's been hard dealing with certain people you know just look at you like you're a piece of garbage. And sometimes it's hard to not feel like that!

On friendships that participants had formed, three of the participants, Priscilla, Geraldine and Jocelyn explained that they had friends but turned to keep very few close. They asserted they said, "hey" to everyone but do have one or two close friends. Participants' responses revealed that although they valued the friendships they formed, they were cautious not to invest their limited time at the shelter into hangouts but instead, concentrating on finding jobs and working on themselves as individuals.

Geraldine: And again, this is not ideal for making a lot of friends. I mean, it's great if you do but it's not designed for that. Because, you are supposed to be working on yourself and/ or your kids. Or whatever the situation is. I will say I have been able to develop some close friendships and we sit together every day, for every meal, all three meals and during snack time and things like that. I just started a new relationship and it's been going okay. We've found ways to communicate with each other. 
It was apparent Geraldine believed her new relationship with her lover could be better outside of the shelter premises. One could tell the conditions at the shelter did not support intimate relationships amongst residents. Communication on a daily basis was cumbersome although she seemed happy with her new lover.

Jocelyn: $\quad$ Yeah, I have a friend who's a resident. She's my neighbor, she's very nice to hang around with. We go places together. She's nice, we get along. The staff is really supportive and hopeful. They really care about the people here and they make you feel at home, they make you feel loved. I can call them if I need anything. Everyone seems to be okay with me but I have just one friend.

She talked about how she and her neighbor were both mothers. They easily bonded while getting tasks completed. This friendship revealed how a number of shelter residents were cautious in their interactions while they form friendships during their stay.

Priscilla: $\quad$ Yes, I have. But I turn to keep to myself. I like to keep my circles, very few people, very few friends. When it comes to friends, I got very few.

\section{Impact of Shelter Living on Family Life}

Participants were asked to discuss the consequences of their stay in the shelter on their families. This main category had sub-categories (follow-up questions) that sought to find out if the shelter stay of mothers has had any repercussions on the lives of their children, and whether they stay in the shelter with children or not. All four participants believed that their stay in the shelter has not impacted extended family members in anyway. They narrated how extended family members have always not been available throughout their childhood lives. Thus, no family member cares.

Priscilla: I have children in the shelter and [another county]. No impact on anybody. Only impacted me and the fact that I am here. I have had 18 years of physical abuse. It's been that long and emotional. No family has been involved. 
Another participant, Albie, who had children outside of the shelter, shared with the researcher the difficulties that come with being separated as a mother from your children. This is what she had to say about the experience:

Albie: $\quad$ My older boys do not like it. They have not been here. Before we came here, I took them to their dads because I don't want them to live in the shelter with me. My girl has no father so I brought her here to live with me. One of my boys talked to me yesterday that he prays every night to see if God could help me get out of here. Giggles! The other boy is also very concerned about me. Anytime I talk to him, I let him know we're okay, we have roofs over our heads, we have beds to sleep, food in our bellies, don't worry about us.

In Jocelyn's case she felt unaccepted by family members' right from childhood and believed societal members could not understand survivors of abuse the way they should. Her religious inclinations have kept her going through out challenging seasons of her life. She also sounded hopeful about tomorrow and believed she will be independent in the future.

Jocelyn: I don't have family that's really there for me. Apart from my step mum and cousin, everyone else distorts me in a way. Which is okay because that's gonna be my testimony one day. All my life, I've always been taken away from people. Nobody wants you around type of person. In tears...God is my best friend really. He never pushes me away.

\section{Learning Experiences}

In this category, participants shared with the researcher learning experiences that come in handy even when they are outside of the shelter. For two of them, Priscilla and Albie, they believed they had proper behaviors, which they had gathered growing up. In addition, they reiterated how significantly their traumatic experiences have shaped their learning experiences. These behaviors do play out even when they are outside of the shelter and not tentatively lessons from the shelter.

Albie: $\quad$ Mmmm, not really. I mean, some people might. My situation and life has been very different than most people in general...I know how to keep myself safe. I know there are a bunch of shady people out there. I am not going to be like, "hi" and try to make friends. It's something I learned at a young age as a military brat, moving around so much. I have been made stronger. 
Even though she believed everyone's situation might be different, her experiences during her childhood has predominantly influenced how she interacts with others outside of the shelter walls. She explained how one's past events did impact the kind of decisions one makes daily. She went on to indicate that any woman in her thirties will know what to do depending on her background.

Priscilla: There are certain things you should already know. When it comes to work service, jobs, how to wash tables, it's common sense. My own self because I know what to do.

According to Priscilla, she believed her maturity contributed to her time outside of the shelter. She noted she knew what to do, and what not do. Hence, she did not rely on any guidance from the shelter during her interactions with societal members.

The other two participants, Geraldine and Jocelyn highlighted the lessons they have learnt while staying at the shelter. In Jocelyn's own words, she said, “They don't make it easy for you. They want you to try, and also to get out there. God has been my strength and I know I can do it". For Geraldine, she narrated how she believed her learning experiences at the shelter would greatly enable her to better manage her finances. This is how she put it,

Geraldine: Yeah, tonight, I will be taking a class based on faith and finances. So I'm hoping to get a lot out of that. I really struggle with money, I'm not very good with money. It's hard for me to admit that, but I do.

\section{Suggestions on Improvements}

In this category, participants were asked to discuss the various ways they believed their subjective experiences could be improved. Regardless of the small nature of the sample, the researcher believes information on participants' perceptions of their experiences may be similar to that of others, and will play a pertinent role in policy making for female survivors of intimate 
partner violence staying in regular shelters. With the exception of one participant, Jocelyn, who felt there was nothing to improve necessarily because she enjoyed her shelter experiences, all the other three participants' discussed various perceptions on how shelter experiences could be improved. Priscilla complained,

Priscilla: It should. In a lot of ways. You want us to strive and become somebody. How can we save money if you make us go out and spend it? They should let people wash their clothes here. They make you go outside to do laundry. Stuff here don't add up. You want me to save, let me wash my clothes at the shelter. Not outside. That's how your money gets out of your check. Let us work the machines down here.

For Albie, she believed the individual relationships could become better if certain restrictions were not in place and residents could be in small groups more often rather than in crowds. This is what she had to say:

Albie: $\quad$ We're all dealing with a lot. I don't know what other people are dealing with, and other people don't know what I'm dealing with, but we are more forced to be in small contained areas at certain periods of time, and everybody is frustrated and having things build up inside, it's easy for the tension to get really thick. But I noticed whenever you sit down and it's a couple of people and you talk, the tension can go away very fast.

Albie went on to lament how she misses her dogs and wished the shelter had a kennel for dogs. She said, "I wish I could still pet dogs. I had to give my dog away before I came here. I miss my dog almost as much as I miss my boys." For Geraldine, she lamented that the shelter does not have support groups for survivors to meet regularly anymore. She believed previous support groups were helpful and needful for residents with a background of abuse on any level. Geraldine asserted, "I would like to see support groups for kids. They are going through stuff too". She continued,

Geraldine: With [name of a battered woman's shelter], they focus on that but this place doesn't focus on that necessarily. I don't know whether that is really good or bad, it's good that they know that there are resources in terms of helping people out to 
other facilities. But if you have a mental health crisis, they don't seem to handle that very well. They rather ship you out to the hospital or Chestnut or to whatever is available at the time. You can get exited very quickly for that and that is something that really bothers me.

\section{Similar and/or Differences in Living Conditions at Shelter from Original Residence}

The participants were also asked to discuss how different and/or similar their living conditions at the shelter were from their original residence, and whether they had friends who they believed shared similar or different opinions. Apart from one participant, Albie, all the other participants had really nowhere to call original residence as they had moved from a number of shelters and/or lived with friends or on the streets for varied reasons.

Priscilla: $\quad$ No difference. There's really no difference. Because, when you're living out there on your own, you still have to come off money, you still need to pay rent...look, I don't know. Something just ain't right. When I do get a job, let me use the laundry room. But they don't make it no easier, you're still struggling. You are coming off money regardless.

For Jocelyn, she decided to use the opportunity to talk about a previous shelter experience she had in another state. She expatiated the differences and similarities she had noticed among shelters. In her opinion, shelter services were related to whether the shelter had a goal of making residents feel relaxed or not. She opined that some shelters were mainly for the healing of survivors while others simply focused on residents becoming independent enough to survive the community outside of the shelter.

Jocelyn: Here, you have staff in the kitchen. With my previous shelters, we were all females so we had a schedule for cooking and everything. It was a healing place. We had caseworkers available for the whole day, so you can talk to them. We had a lot of meetings from nutrition, domestic violence, and people were coming in and it was mandatory. Here, there's nothing like that. That's the difference. Here, they don't want you to be comfortable so you don't wanna leave. You signed up for using the washer and dryer. You signed up for it, but you use it when you want to use it. Whatever the case may be. They just want you to stay at home. Here, they want you to go out there and do something for yourself. If they make it 
comfortable for you, you will not like to leave. For how similar, maybe just being in the shelter. I don't know.

Geraldine enjoyed her time at the current shelter and expressed how much the staff are concerned about residents and always ready to assist them, including compromising for them when the need arises. She explained her prior shelter was not the same as she had unpleasant experiences, without any attention or assistance from the shelter director. She also asserted that other residents would have their own peculiar encounters.

Geraldine: I thought, you know...shelters were here to help people. But I never was very clear on to what extent and in what ways. I feel like in this environment that has improved greatly. Because again they have classes and it's not like you can stay here, but you are on your own otherwise. So, we are able to get classes and also able to help ourselves and things like that. It is kind of...to an extent that they help other people. I feel like it's broadened to an extent that they help other people.

Albie on the other hand believed her previous residence was very different and unique in itself. She narrated how she and her child came from living on a farm. She believed staying at her current shelter was quite different. However, she liked some things about her new home. She lamented about the loss of freedom to decide what one could cook for meals. She expressed her unhappiness about restrictions that came with the use of home appliances and believed other residents have had their own unique encounters at the shelter.

Albie: $\quad$ Mhmm...giggles...It is more different than I can even say. We lived in a farm, a nature preserve. To come here...quite different, quite different. There are some nice things about being here. I know there are people that will love to be in here but everybody that's in here will love to not be. It's all on perspectives I guess. I do miss having the freedom to go to the kitchen as I please...I definitely miss being able to cook [child's] scrambled eggs in the morning...having a say in what I eat...which I mean, kind of now, but they still don't have a microwave in the living room. We're allowed to have food in the women's lounge now, we're still allowed to bring cold food from the gas station. It's not like we can cook something for ourselves... Just the main kitchen where they serve the meals...There's no say in what we have and that's the biggest challenge for a lot 
of us...Women will like to come in to microwave some ramen noodles sometime or whatever.

She went on to explain how all residents were taking significant steps to get a place of their own, with the exception of one resident who wanted to keep staying at the shelter, because he enjoys being around the people. She opined that shelter staff might believe all residents were excited and comfortable with their shelter stay, although this perception may be misleading.

Albie: $\quad$ Everybody would have different opinions... we each have our own different experiences with staff. I know some people...um...have left because of it, and said they will rather sleep on the streets but those are single men, that have much right to just say, I'm not gonna let people talk down to me... I'm gonna go. And I have only seen one woman leave here that wasn't kicked out. So whenever we as other residents see other residents getting kicked out for little things... It makes all of us very nervous. Like wuhoo... everybody walks on eggshells right now. It's very cold and none of us wanna get kicked out before we have the money to get into our own place. All of us are trying. There's only one person that I have heard is comfortable with being here. And is like...I'm just gonna stay here as long as I can. Like everyone else is trying to do what they have to do to get their own place. But at the same time we're not treated like that...it's like they think we're happy here...even though we try to make the best of it...none of us is happy being here

\section{Opinion of Shelters Prior to Shelter Stay}

In this main category, participants discussed what they thought about shelters before their current stay. More so, some participants who had a change in opinion also shared their current perceptions with the researcher. The participants had varied opinions because of the differences in their shelter encounters and varied length of stay in shelters. In addition, participants' background as survivors of abusive relationships influenced the different shelter encounters they had. For one of the participants, Priscilla, it was patent that she was dissatisfied with her shelter experiences in general.

Priscilla: $\quad$ Full of crap, because that's how I feel today. Because either they want your money or they want you to go spend it. And the thing about this is...mehnn. I was 
in a shelter before this. And they wanted $5 \%$ of the check that I was bringing in. And you want me to spend 100 something dollars for a whole 30 days. And you put me outside from 8: 00am in the morning to 5:00pm at night, where am I going? So, when you go sit in subway or a restaurant or something...you have to come off that money.

Jocelyn on the other hand believed shelters had a bad reputation for outsiders and every shelter offers unique experiences for residents. In her view, society gives a false impression about shelters. She acknowledged that she felt blessed to be part of a caring community.

Jocelyn: $\quad$ All shelters are different. They have their own ways and what not. Shelters are just there to help you. People make it look like...oh my gosh, homeless shelters. People just distort it. It has an outlook for people who are outside. I was in a first shelter and I said, oh my God, I don't wanna do this. But I knew I had to. Being in there, it really helped me. If you think about it, it's a blessing to have people who care, to have people that want you to do better. You don't have to pay rent, you don't have to pay anything. It's the community looking out for each other. So you see the opposite of what a stereotype does... eeeeee homeless shelter.

Geraldine expressed her contentment with her current shelter stay when she was asked to share her opinion about shelters. However, she had encountered unpleasant events that creates discomfort during her stay. Hence, she had a nuanced account to share. She reiterated that other shelters were messy, but she liked her current shelter.

Geraldine: It gets messy and chaotic here sometimes. It's better here than my previous shelters. A few guys have put me on edge a couple of times. Just with the way they act, their body language, they stare, and they make you uncomfortable. Sometimes it's hard to address that. It almost makes you feel like you are just left to build your own defenses to deal with and that's not very easy. In this situation, there's not a safe way to deal with. How are you to develop safety if you are supposed to be just as cautious especially with a background of abuse?

Albie on the other hand had not thought of having to stay in a shelter until she noticed there was a need for her to take that step for her good, and for the welfare of her children. In her own words, 
Albie: $\quad$ Mhmmm, you know, I had never really thought about it much before I probably realized I had to go somewhere else because of my children in order to have more opportunities...I did not think it will take 3 months...I thought there will be a big room with a bunch of bunk beds where people come in and sleep. It's not like that at all...there are a lot of rules and it's hard to keep track of so many rules. I like that mothers with kids get their own separate rooms. I didn't really have an opinion.

She continued by throwing more light on her previous shelter experiences even though she believed that all shelters were different from one another.

Albie: $\quad$ The shelter I went to when I was divorced, the domestic violence shelter...we had a big kitchen and it was like a house. Bedroom were upstairs, and we could have our own rooms with our own keys and were able to fix our children's meals. So that was very different from here where we are not allowed to lock the door and they are allowed to go through our stuff, whenever they want...I think every shelter is different. Apparently.

She was undoubtedly unhappy that the current doors of mothers' rooms had no locks and staff were permitted to go through the stuff of residents, which was not the case during her previous shelter stay [another shelter]. She continued by saying that, “...It's not that I have anything to hide but whenever I go through and see like, ewww...you went through my underwear... I feel a little bit invaded you know. You see what I mean. It's different from my previous shelter experience"

\section{Summary}

All participants believed shelters had been helpful by providing them with a place to stay and resources to improve their experiences. They outlined differences and opined that shelters have different foci, regardless of the general aim of providing a safe place to sleep. Only one participant had no previous shelter encounters. Participants had varied opinions on their current shelter stay. Two participants (those without jobs) found it stressful while the other two participants (with part-time jobs) believed their stay was all right, based on their comments. All 
participants also shared that they felt safe at the shelter, even though their comments on safety were individualistic.

Forms of support participants received varied. These included emotional support through social relationships with other residents and nice staff members. Physical resources like bus passes were also highlighted amongst participants even though some said bus passes were limited at times and were only made available to residents with medical conditions to the neglect of residents who might need to attend job interviews. One participant also shared how she now has a different view of Christianity after seven (7) years of abuse by her step-dad who was a pastor at the time. She also emphasized how the shelter met her spiritual needs. Even though, emotional support was the most common need met according to all participants through their friend groups and staff, one resident who had been in and out of the shelter recounted a previous support group which she found very valuable to her stay as a survivor. Another participant admitted the shelter gave residents a referral if one suffered any form of mental illness. She emphasized one could easily be evicted from the shelter due to a mental condition and lamented the shelter did not handle such cases well.

It is obvious that children outside the shelter are unhappy about the separation from their mothers and in no doubt, disturbed. One can infer that children who stay at shelters with mothers are also going through their own phases of traumatic experiences and the role of support groups will be needful for them as well, as suggested by one of the participants. Other participants gave the researcher the impression that they felt shelter staff often treated residents with disdain and this could possibly lead to a lot of residents exiting the shelter. Staff-client relationship existed at the shelter and not necessarily friendships with staff, as participants explained. 
Participants' built friendships with other residents but also reiterated that the shelter was not made for that purpose. Participants also believed their experiences as shelter residents had not impacted extended family in any way but those with children outside of the shelter shared how the separation has been difficult for children as well. Participants shared how they had suffered abuse right from childhood and had no one who really cared. On learning experiences, one participant shared how shelter experiences have made her strong to face the outside world while for another; she believed shelter experiences would help her better manage her finances. The other two participants believed their background and who they are as self-disciplined individuals does play out when they are outside of the shelter.

On suggestions on improvements, only one of the participants felt there was nothing to improve necessarily because she enjoyed her shelter experiences. All the other three participants discussed various perceptions on how shelter experiences could be improved. One participant highlighted the need for support groups for survivors as well as children. Another believed there was the need to create healthy atmospheres through the creation of large spaces to accommodate residents in smaller groups, so no one feels another resident was irritating him or her. Again, another resident believed it will be helpful if residents were given the opportunity to do their laundry at the shelter in order to save up money rather than doing laundry outside of the shelter. Apart from one participant who explained her original residence was a nature preserve, all other participants had previous shelter experiences and/or had been living on the streets. The group without an exact original residence had varied opinions. One participant believed all shelters were the same, another participant thought other shelters could get very messy while another participant believed shelters varied even though they are meant to cater for the needs of homeless populations. Only one participant disagreed with the opinion of the other three 
participants that other residents will have unique perceptions of how similar and/or different their shelter experience compares to their original residence.

Finally, participants discussed their previous opinions of shelters prior to their stay and also shared their present opinions as shelter residents. One participant highlighted how she taught shelters were filled with crap and how that had not changed at the time of the interview. For another participant, she felt blessed staying at the shelter and believed that outsiders had a bad outlook of shelters. Two other participants also said there were nice things about the shelter. Moreover, for one of them, she explained she did not really have a previous opinion of shelters. The other participant did believe other shelters could get messy but not where she stayed at the time of the interview. 


\section{CHAPTER V: DISCUSSION}

This study sought to identify the experiences of women who had survived intimate partner violence as residents of regular shelters. The researcher was interested in the subjective account of their experiences as previous studies has failed to give attention to the needs of survivors who stay at shelters and has focused predominantly on survivors in domestic violence shelters. More so, the researcher was interested in the forms of support made available to them in the shelter, and what more services in their opinion as residents could improve their experiences. The study was exploratory.

The researcher conducted four semi-structured qualitative interviews with survivors of intimate partner violence at a homeless shelter in Bloomington-Normal, Illinois. The openended nature of the interview guide allowed participants to freely share their experiences without any restrictions, while guided to ensure every pertinent detail for the purposes of understanding their experience had been covered. This chapter discusses the study's findings, limitations, and implications.

Data on demographics revealed that survivors of intimate partner violence who end up as residents of shelters do not stay there for more than 12 months. This can be corroborated with findings from a study by Haj-Yahia \& Cohen (2009), which revealed that residents of abused women's shelters typically stay for up to eight months. At the time of the interview, residents were all single and two participants had part-time jobs while the other two were looking for jobs. These findings align with studies by Haj-Yahia \& Cohen (2009), which also explained that when women leave their abusive husbands they turn to seek housing in shelters and begin to get paid jobs in order to be able to meet their personal needs and to support their children while at the 
shelter. Although some participants stayed at the shelter with their children, three mothers had some of their children staying outside of the shelter with their ex-lovers and/or husbands. This situation of separation of mothers and their children confirms studies by Cowal et. al (2002), which reported that mothers living in shelters are much more likely to be separated from one or more of their children than are mothers with public assistance who have not struggled with homelessness.

Apart from questions six, seven and eight that elicited themes that focused on improvements of the shelter experiences of residents, questions one to five generated themes that highlighted the personal experiences of the residents as well as the impact of their shelter living on extended family members and/or children. All participants shared various ways through which the shelter has been helpful to them. This finding is buttressed by a study conducted by Gordon (1996), which revealed that survivors from abused relationships typically found their stay at shelters as a coping strategy, even though survivors do not commonly use shelters. Two participants were very positive about their experiences but were very emphatic about the fact that one could have fewer issues with staff if only one obeyed instructions from staff. For the other two, one was ambivalent about her experiences overall while the other was very negative and felt pressured on every side. These findings are similar to that of Haj-Yahia and Cohen's study in 2009 which also stated that the experiences of residents of shelters do vary especially based on the kind of relationships they may have with shelter staff and/or other residents. One can also conclude that, the two participants that were not positive about their experiences may be spending a lot of hours at the shelter especially because they were jobless at the time and might be stressed by being indoors more often. 
Women were also happy about the different forms of support they received from the shelter. For Albie she talked about the resources that she had been able to access due to her shelter stay. Priscilla also appreciated the fact that residents could have access to bus passes but complained this resource was in limited supply. It is also noteworthy that women particularly highlighted emotional support as the form of support that has been most relevant to them. For Geraldine, she appreciated the love and the concern she received from staff members. The role staff members played by showing concern for the well-being of residents can be corroborated with Haj-Yahia and Cohen's study in 2009, which revealed that some women described the love, availability, flexibility, and intimacy between the staff members and residents. One participant, Albie advocated for being in smaller groups rather than large groups in order to ease the tension that builds up when there are many people in a small-restricted area.

All participants did highlight the emotional support that comes from the friendships they have built with other residents. It was apparent every participant had her own friend group as they reiterated how they kept very few friends and the fact that the shelter was not meant for friendships necessarily. On the consequences of shelter living of residents on extended family members and/or children, three of the participants expressed how they had abusive backgrounds and really did not have any extended family member who cared. One participant emphatically shared how it had only affected her. She said, "It has only impacted me. I have had eighteen years of physical abuse. It has been long and emotional." Two other residents shared how they had missed their children and how hard the separation has been for them and the children. Albie shared how one of her boys told her on the phone he prayed that God would help her quit staying at the shelter. 
Another study by Mcnamara in (2008) confirms the difficulties children go through when they are separated from their mothers and how that becomes a daily burden for them. It is worth mentioning that two of the participants felt strengthened by their shelter experiences while the other two discussed how their background of abusive encounters had shaped how they carried themselves about when outside of the shelter walls. The process of dealing with communal living and having to learn the skills of becoming independent has been described by previous studies as some of the ways staying at shelters strengthened residents. In addition, previous studies on survivors living in a domestic violence shelter revealed how women continued to be supportive of one another even outside the shelter. This study did not have such findings and one could conclude this was because residents were survivors who stayed in regular shelters, which was not designed as an abused women's shelter.

Although one participant thought everything was fine and suggested no improvements, the other participants discussed ways they believed their shelter experiences could be improved as residents. Geraldine highlighted the need for support groups for children as they also find shelter living challenging just like the adults. She lamented previous support groups for women were no more and how much she would love to see that restored. For Albie, she discussed the need to have small groups in large areas rather than large groups in very small-restricted areas as that generated a lot of tension and confusion amongst shelter residents. She also discussed how she believed having a kennel for dogs would be very beneficial especially in cases where survivors had to leave their dogs behind because pets were not allowed in the shelter.

From this study, only one participant shared her original residence as a nature preserve while the other three shared how they had lived in previous shelters and/or on the streets. It was apparent from their responses that two of the participants had adjusted to communal living and 
believed shelters had been created to be helpful to them. However, the other two participants found their stay at the shelter very stressful. One can conclude this was the case especially because the other two did not recount many previous shelter experiences. Finally, only one participant, Priscilla discussed how she had thought shelters were unkempt, had rigid rules, and still thought same. Two participants, Albie and Jocelyn thought the shelters were alright even though they believed outsiders had a very bad perception of shelters. Albie buttressed her comments by discussing how her child's dad would not bring him to visit her at the shelter because he did not want his son to see the place.

\section{Limitations}

This study focused on the experiences of women who have survived intimate partner violence and are living in regular shelters. One of some of the hindrances to the study was sample size. The researcher had the opportunity to interview four Caucasian women of a homeless shelter in Bloomington-Normal, Illinois. This sample was small even though it did clearly reveal that there were survivors in regular shelters who still did have special needs, with a background of domestic violence. One can allude this event to the fleeting nature of the homeless population. This is because, the researcher was informed of about four residents who showed interest in the study but left before they could sign up to participate. The narratives of the four who were able to participate offer a wealth of information that will be needful for shelter practice.

There are four other regular shelters in the same town, where the researcher could possibly seek admission if there would have been ample time in order to increase the sample size, as well as permit heterogeneity in the sample. However, due to time restrictions, the researcher was not able to do so. In addition, a researcher might be able to overcome this 
challenge of sample size if she were to volunteer at the shelter prior to the study in order to build relationships and rapport with prospective respondents. More so, apart from an informational session, a researcher could find out if there are any meetings and/or support groups that one could attend to establish some rapport with prospective participants.

Furthermore, during the interview sessions there were times that participants found it difficult to continue the discussion especially when they were asked about how their stay at the shelter had affected their extended family and/or children. For some participants, they shed tears as they narrated they had experienced abuse from the hands of their own parents as well as their partners. For other residents, the separation from their children and their dogs had been tough for them. Discussing mother-child phone conversations with the researcher aroused an emotion of sadness for a period.

Bias of participants might also be a limitation of the study. After the informational session, participants signed up with case managers based on their interest to participate. A participant might give very positive responses to questions, with the mindset of pleasing a case manager. An event like this might influence the accuracy of the information received by the researcher.

Finally, the issue of generalizability is also another limitation to be considered. The sample size highlighted four residents' experiences at a shelter in Bloomington-Normal, Illinois. This sample consisted of only Caucasian women. This sample cannot be applied in terms of the experiences of other women of different races or in other areas. However, the experiences of these white women do allow a glimpse into the shelter stays of white women in this area. 


\section{Recommendations and Conclusion}

Findings from the study reveal that survivors who live in shelters appreciate the relationships that arise because of communal living. Residents do acknowledge the assistance of staff and the many resources that are made available to them. However, residents also highlighted the insufficiency of some resources like bus passes and lamented they did not have the opportunity to do their laundry free at the shelter. It is apparent survivors will find it more helpful if shelter management grants them the opportunity to do their laundry free. In addition, shelters should organize laundry supply drives, in order to offer residents laundry detergents, drying sheets and any other laundry supplies they may need, to reduce the cost of doing laundry for residents. This assistance will undoubtedly make it possible for residents to save up on the expenses they make for their laundry.

Participants believed in sharing their struggles with other residents within small groups. One participant buttressed this point by explaining how tension easily built up whenever they as residents found themselves in small confined spaces, especially due to overcrowding. The researcher believes survivors should be given the opportunity to share their burdens within small groups. As they share their struggles, they will be on the journey to solving them. In addition, shelter management could play a significant role in reducing the tension that builds up among residents. This can be done by minimizing the large numbers of residents who share shelter spaces at a particular time of the day. All residents with their children should not be compelled to

share small spaces in order to reduce overcrowding, as well as tensions that can easily erupt when people feel like they are competing for space. In addition, it will be much easier for residents to quickly resolve their differences within small groups rather than in large groups. 
Residents also discussed the varied relationships that existed between staff and residents. Some of them shared how staff showed love and concern towards them while others felt staff treated them with disdain. It is a known believe that the shelter experience can be stressful for residents, especially for those who have struggled with abuse. More so, working at the shelter might be overwhelming for staff especially when dealing with numerous cases over a period.

The researcher believes that during training sessions for staff, they should be educated on how best to use respectful verbal and non-verbal forms of communication with residents, in order to contribute to their successful stay at the shelter and their lives in general. Residents are usually burdened with the stigma that society attaches to homelessness and the discrimination that comes with going through homelessness and the experiences of shelter living. Consequently, shelter staff could contribute to residents' positive self-esteem by treating all of them with respect and letting them know they are valued and are capable of becoming independent against all odds. This positive support for all residents irrespective of their race and level of relationship with staff members will go a long way to increase their positive self-esteem during and after their shelter stay. Moreover, shelters are more likely to close the empathy gap between shelter staff and residents in situations where shelter staff are survivors as well.

One participant expressed her unhappiness with the inspection of their wardrobes, which she believed does invade privacy and closes the door of opportunity to create their own private spaces. This response is worth mentioning especially because of how the feeling of invasion of privacy could lead women to relive their experiences of abuse (Haj-Yahia \& Sadan, 2003). The researcher suggests that shelter management should limit the autonomy shelter staff have over inspecting survivors' wardrobe especially because of their past traumatic experiences. It would be healthier for survivors if they do not keep feeling invaded or reminded of their abuse, anytime 
their wardrobes are inspected, without their knowledge. Management of shelters should give residents advanced knowledge of any wardrobe inspections or make a schedule for such purposes, especially for survivors of IPV. In addition, residents should also be granted the opportunity to lock their doors to prevent the invasion of privacy.

Another participant suggested that support groups be created for both children and survivors as these groups of people were going through their own struggles because of abusive backgrounds. One can also deduce from the interviews that survivors who had jobs spent fewer hours at the shelter as compared to those who had no jobs. Thus, it is more likely that survivors who had no jobs were disturbed on many occasions and were easily irritated at the shelter. The researcher believes shelter management should play a paramount institutional role in reducing unemployment amongst residents by offering referrals to agencies they are aware have open positions that specific residents could fill. In addition, employment of career counselors who could help residents prepare for interviews as well as rethink their career options will be a great asset for shelters. Shelters should also introduce more vocational training classes based on the career interests of residents. Science, Technology, Engineering and Mathematics (STEM) classes in website and mobile app development can also be introduced to equip residents with skills, to improve their employability.

More so, shelter management should also be of immense support to residents, by soliciting for bus passes in the form of in-kind donations. This will invariably increase the number of bus passes available for residents' use. This assistance will greatly reduce the inconvenience caused by the lack of transportation to interview locations which survivors reiterated was a great challenge for them. 
Moreover, residents who might be in the process of finding jobs should be given the opportunity to offer volunteer hours, in or outside of the shelter. Shelter management should arrange for interested residents to learn a craft in ceramic art, paper craft, and jewelry, among others. This opportunity is likely to reduce boredom for residents who might be in the process of finding paid jobs.

Furthermore, one could deduce from the accounts of participants that they all struggled with relationships one way or the other. Shelters should incorporate relationship workshops when planning programming for residents. Especially, female survivors. Workshops on relationships will be very beneficial for women as they address the relationship difficulties they might have with ex-lovers, current lovers, and family relations, as well as relationships they form within the walls of the shelters.

It is also worth mentioning that participants reiterated the challenges they had with their mental health especially due to their abusive experiences. It was also lucid to the researcher that participants who struggled with their mental health could easily be kicked out without any consideration given to their statuses as victims of homelessness. This situation was of particular concern for two of the participants who believed coming out to seek extra support could open the door to their eviction, even though they might not be independent enough to exit the shelter.

Management of shelters need to reduce the fear amongst residents with mental health struggles, by offering mental health training for shelter professionals, to serve as the first point of call for residents, prior to connecting them with mental health facilities. In addition, shelters should also invest resources into creating regular psychiatrist visits for the benefit of survivors who might be struggling with mental health disorders and require extra support. The hiring of inhouse psychiatrists will also be beneficial, especially for residents with mental health challenges. 
Management of shelters should also create a kennel for survivors who might have dogs prior to their shelter stay. One of the participants, Albie, mentioned how she had to part company with her dog because pets were not allowed at the shelter. Studies have proven dogs and pets in general have a great therapeutic impact on human beings (Harkrader, Burke \& Owen, 2004). Hence, the presence of dogs especially at the shelters would help residents reduce stress and facilitate the healing process of residents with mental health disorders.

Furthermore, it is also noteworthy that, survivors have been troubled by the negativity that comes from the outside world as well as shelter staff. Amidst their shelter experiences, participants reiterated the overwhelming impact of shelter rules, which they have found inconsistent among staff members. Shelters should be hopeful about the success of all residents and positively communicate with residents as they work towards their independence outside of the shelter. Shelter staff should also be consistent with shelter rules, in order to avoid any form of confusion in the minds of residents. Shelter management should also assure residents that, they are not all by themselves as they experience homelessness, and shelters are not only in operation to offer them a place to sleep. Shelters should also portray the confidence they have in residents' success by highlighting the positive attitudes of residents instead of dwelling on their negative habits throughout their stay.

Finally, shelter management and members of staff can contribute greatly to the overall well-being of residents by being empathetic towards them. All survivors narrated their childhood abuse and the extent to which family members have neglected them because society has labeled victims of homelessness as "bad people." Furthermore, the availability of open kitchens to residents will help them feel less helpless, will build agency, help residents bond a lot more and will help residents especially mothers replicate some of their traditions in their original homes. 
For instance, making breakfast for their children. It will be needful for service providers who have a purpose to help survivors piece their lives together, to treat them with value. These survivors should receive hope from case managers, social workers, visiting attorneys and all other professionals who play a significant role in their development. All stakeholders should be aware of the fact that the success and/or failure of survivors is their success and/or failure as well. Hence, there is the need for an intentional institutional commitment, responsibility and care towards the needs of survivors and shelter residents as a whole.

Previous studies have considered the awareness of DV, its prevalence and effects as a social issue. However, the subjective experiences of women who have survived intimate partner violence and stay at regular shelters have been given less attention. This current study highlights the fact that the population in question do exist and the need for shelters, practitioners, researchers as well as policy-makers to address their experiences and concerns. Future studies should focus on contributing to the literature on women who have survived intimate partner violence and have unique experiences during their stay at homeless shelters. This great step will not only influence literature but will also influence policy decisions for the improvement of shelter practice, to the benefit of residents, shelter management and society as a whole.

The current study focused on female survivors of IPV at a homeless shelter in Illinois. However, according to Homeless Shelter Directory (2018), there are more than 40 (forty) homeless shelters in Chicago alone. Shelters often times have lengthy waiting lists and some potential residents are turned away due to limited beds. This highlights the great portion of survivors who have been overlooked. It is apparent many survivors are currently going through different shelter experiences and their unique background needs to be considered by shelter administrators and policy makers in decision-making. 
Ultimately, the current study mainly focused on the Midwestern part of the nation. Hence, there is the need for further studies to tackle other shelters in the Northeast, Southwest, West and Southeast regions of the nation. This consideration will allow for a more integrated study of the experiences of female survivors of intimate partner violence who stay at homeless shelters. More so, such comprehensive studies will allow researchers to make comparisons in survivors' shelter stays and allow for meaningful deductions on programs that are successfully contributing to the independence of survivors with respect to shelters and their locations. 


\section{REFERENCES}

Agnew, V. (1998). Abused Women and Culturally Sensitive Services. Toronto: University of Toronto Press

Anderson, K., L. (1997). Gender, Status, and Domestic Violence: An Integration of Feminist and Family Violence Approaches. Journal of Marriage and the Family, 59(3), 655-669.

Arrighi, B. (1997). America's Shame: Women and Children and the Degradation of Family Roles. Westport, CT: Praeger. 2-61

Averitt, S., S. (2003). Homelessness is not a Choice!: The Plight of Homeless Women with Preschool Children Living in Temporary Shelters. Journal of Family Nursing 9(1), 79100

Bassuk, E., Buckner, J., Weinreb, L., Browne, A., Bassuk, S., Dawson, R., \& Perlojf, J. (1997). Homelessness in Female-headed Families: Childhood and Adult Risk and Protective Factors. American Journal of Public Health 87, 1- 241

Black, M.C, Basile, K.C., Briedling, M.J., Smith, S.G., Walters, M.L., Merrick, M.T., Chen, J., and Stevens, R. (2011). The National Intimate Partner and Sexual Violence Survey (NISVIS): 2010 Summary Report. Atlanta, GA., National Center for Injury Prevention and Control, Centers for Disease Control and Prevention

Bowker, L. H., \& Maurer, L. (1985). The Importance of Sheltering in the Lives of Battered Women. Response to the Victimization of Women and Children, 8, 2-8

Browne, A., \& Bassuk, S. S. (1997). Intimate Violence in the Lives of Homeless and Poor Housed Women: Prevalence and Patterns in an Ethnically Diverse Sample. American Journal of Orthopsychiatry, 67, 261-278 
Campbell, J., Webster, D., Koziol-McLain, J., Block, C., et al. (2003). Risk Factors for Femicide in Abusive Relationships: Results from a Multisite Case Control Study. American Journal of Public Health, 93(7), 1089-1097

Chang, D. B. K. (1992). A domestic violence shelter: A symbolic bureaucracy. Social Process in Hawaii,34, 37-52

Cosgrove, L., \& Flynn. (2005). Marginalized Mothers: Parenting without a Home. Analyses of Social Issues and Public Policy 5(1), 127-145

Cowal, K., Shinn, B., Weitzman, D. Stojanovic, Labay, L. (2002). Mother-child Separations among Homelessness and Housed Families Receiving Public Assistance in New York City. American Journal of Community Psychology 30, 30-711

Davidson, B. P., \& Jenkins, P. J. (1989). Class Diversity in Shelter Life. Social Work, 34, 491494

Dobash, R. E., \& Dobash, R. P. (1992). Women, Violence, and Social Changes. London: Routledge

Dobash, R. E., \& Dobash, R. (1987). The Response of the British in the American Women's Movement to Violence against Women. In Joan, B, C., \& Jean, S., S. (1989). Shelters An Alternative to Violence: A Psychological Case Study. Journal of Community Psychology, 17, 203-205

Dobash, R., E. \& Dobash, R. (1979). Violence against Wives: A Case against the Patriarchy. New York: Free Press

Donnelly, D. A., Cook, K. J., \& Wilson, L. A. (2004). Provision and Exclusion: The Dual Face of Services to Battered Women in Three Deep South States. Violence against Women, 10, $1015-1035$ 
Dutton, D. G. (2006). Rethinking Domestic Violence. Vancouver: University of British Columbia Press. In Rodriguez-Menes, J \& Safranoff, A. (2012). Violence against Women in Intimate Relations: A Contrast of Five Theories. European Journal of Criminology 9(6), 584- 602

Edelman, M., W.\& Mihaly, L. (1989). Homeless Families and the Housing Crisis in the United States. Children and Youth Services Review, 11, 91-108. Retrieved September 18, from http://www.sciencedirect.com/science/article/pii/0190740989900091

Eisikovits, Z., \& Buchbinder, E. (2000). Locked in a Violence Embrace. Thousand Oaks: Sage

Epstein, S., Russell, G., \& Silvern, L. (1988). Structure and Ideology of Shelters for Battered Women. American Journal of Community Psychology, 16, 345-367

Evans, R. D \& Forsyth, C.J. (2004). Risk Factors, Endurance of Victimization, and Survival Strategies: The Impact of the Structural Location of Men and Women on Their Experiences within Homeless Milieus. Sociological Spectrum, 24, 479-505

Felix, A. D. (2004). Life without Walls: Violence and Trauma among the Homeless. In Goodman, L., Fels, K., \& Glenn, C. (2006). No safe place: Sexual Assault in the Lives of Homeless Women. Harrisburg, PA: VAWnet, a Project of the National Resource Center on Domestic Violence/Pennsylvania Coalition against Domestic Violence. Retrieved July/17/2017, from http://www.vawnet.org

Feltey, K., \& Nichols, L. (2002). Homeless Women with Children in Shelters: The Institutionalization of Family Life. In H. R. McNamara (Ed.), Homelessness in America (pp. 114-124). Westport, Connecticut: Praeger Publishers 
Fleming, J. (1979). Stopping Wife Abuse. New York: Anchor books. In Joan, B, C., \& Jean, S., S. (1989). Shelters - An Alternative to Violence: A Psychological Case Study. Journal of Community Psychology, 17, 203-205

Friedman, D., H. (2000). Parenting in Public: Family Shelter and Public Assistance. New York: Columbia University Press, 140

Garza, M. A. (2002). Evaluation of a Battered Women's Shelter: Outcomes to Measure Effectiveness. Unpublished Ph.D. dissertation, The Johns Hopkins University, Maryland, USA

Gelles, R., J. (1974). The Violent Home. Beverly Hills, CA: Sage

Gerson, J. (2006). Hope Springs Maternal: Homeless Mothers Talk about Making Sense of Adversity. New York: Gordon Knot Books

Glasser, I. (1994). Homelessness in Global Perspective. (n.p): G. K. Hall

Glenn, R. C. (2010). Living with and within the Rules of Domestic Violence Shelters: A Qualitative Exploration of Residents' Experiences. Retrieved July,18, 2017 fromhttps://dlib.bc.edu/islandora/object/bc-ir:101249/datastream/PDF/view

Golden, S. (1992). Women Outside: Meanings and Myths about Homelessness. California: University of California Press. In McNamara, H., R. (2008). Homelessness in America. Connecticut: Praeger Publishers

Gondolf, E. W., \& Fisher, E. R. (1988). Battered Women as Survivors: An Alternative to Treating Learned Helplessness. Lexington: Lexington

Goodman, L. A. (1991). The Relationship between Social Support and Family Homelessness: A Comparison Study of Homeless and Housed Mothers. Journal of Community Psychology, $19,321-332$ 
Goodman, L. A. \& Epstein, D. (2008). Listening to battered women: a survivor-centered approach to advocacy, mental health, and justice. Washington, D.C.: American Psychological Association

Goodman, L., Fels, K., \& Glenn, C. (2006). No Safe Place: Sexual Assault in the Lives of Homeless Women. Harrisburg, PA: VAWnet

Goodman, L. A., Dutton, M.A., \& Harris, M. (1995). Episodically Homeless Women with Serious Mental Illness: Prevalence of Physical and Sexual Assault. American Journal of Orthopsychiatry, 65, 468-478

Gordon, J. S. (1996). Community Services for Abused Women: A Review of Perceived Usefulness and Efficacy. Journal of Family Violence, 11, 315-329 doi:10.1007/BF02333420. In Haj-Yahia, M.M. \&Cohen, H.C. (2009). On lived experience of battered women residing in shelters. Journal of Family Violence, 24 (2), 95-109

Haaken, J. \& Yragui, N. (2003). Going Underground: Conflicting Perspectives on Domestic Violence Shelter Practices. Feminism \& Psychology, 13, 49-71

Haber, M., G.\& Toro, P.A. (2004). Homelessness among Families, Children, and Adolescents: an Ecological-developmental Perspective. Clinical Child Family Psychological Review, 2004 September; 7 (3): 123-64

Haj-Yahia, M.M. \&Cohen, H.C. (2009). On Lived Experience of Battered Women Residing in Shelters. Journal of Family Violence, 24 (2), 95-109

Haj-Yahia, M. M., \& Sadan, E. (2003). Ha'atzamat nashim mukotbehevrot kolektivistiot [Battered Women in Collectivist Societies: Intervention and Empowerment]. Unpublished paper (Hebrew) 
Harkrader, T., Burke, T., \& Owen, S. (2004). Pound puppies: The rehabilitative uses of dogs in correctional facilities. Corrections Today, 66(2), pp. 74-79

Hoff, L. A. (1990). Battered Women as Survivors. London: Routledge. In Haj-Yahia, M.M. \& Cohen, H.C. (2009). On Lived Experience of Battered Women Residing in Shelters. Journal of Family Violence, 24 (2), 95-109

Holden, D. (1997). “On Equal Ground”: Sustaining Virtue among Volunteers in a Homeless Shelter. Journal of Contemporary Ethnography, 26, 117-145

Homeless Shelters Directory. (2018). Chicago Homeless Shelters and Services for the Needy. Retrieved from https://www.homelessshelterdirectory.org/cgi- bin/id/ city.cgi?city=Chicago \&state=IL

Johnson, M., P. (1995). Patriarchal Terrorism and Common Couple Violence: Two Forms of Violence against Women. Journal of Marriage and the Family 57(2): 283-294

Kim, J., Y. \& Sung, K. (2000). Conjugal Violence in Korean American Families: A Residue of the Cultural Tradition. Journal of Family Violence 15(4), 331-345

Krishan, S., \& Hilbert, J. C., (1998). In Search of Sanctuary: Addressing Issues of Domestic Violence and Homelessness at Shelters. Women's Health Issues, 8, 310-316. In Living with and within the Rules of Domestic Violence Shelters: A Qualitative Exploration of Residents' Experiences. Retrieved July 18, 2017, from https://dlib.bc.edu/islandora/object/bc-ir:101249/datastream/PDF/view

Kasturirangan, A., Krishnan, S., \& Riger, S. (2004). The Impact of Culture and Minority Status on Women's Experiences of Domestic Violence. Trauma, Violence, and Abuse 4:318332. In Rodriguez-Menes, J \& Safranoff, A. (2012). Violence against Women in Intimate Relations: A Contrast of Five Theories. European Journal of Criminology, 9(6), 584- 602 
Lee, B. A., \& Shreck, C. J. (2005). Danger on the Streets: Marginality and Victimization among Homeless People. American Behavioral Scientist, 48, 1055-1081. In Rodriguez-Menes, J \& Safranoff, A. (2012). Violence against Women in Intimate Relations: A Contrast of Five Theories. European Journal of Criminology, 9(6), 584- 602

Lemon, N. K. (1996). Domestic violence law: A comprehensive overview of cases and sources. Austin \& Winfield Publishers

Lindsey, E., W. (1998). The Impact of Homelessness and Shelter Life on Family Relationships. Family Relations, 47(3), 243-252

Martin, D. (1976). Battered wives. (n.p): Volcano Press

Mayhall, P. D., \& Norgard, K., E. (1983). Child Abuse and Neglect. New York: Wiley. In Joan, B, C., \& Jean, S., S. (1989). Shelters - An Alternative to Violence: A Psychological Case Study. Journal of Community Psychology, 17, 203-205

McDonald, J. (2005). Neo-liberalism and the Pathologising of Public Issues: The Displacement of Feminist Service Models in Domestic Violence Support Services. Australian Social Work, 58, 275-284

McNamara, H., R. (2008). Homelessness in America. Westport, Connecticut: Praeger Publishers. Marin, M.\& Vacha, E. (1994). Self-help Strategies and Resources among People at Risk of Homelessness: Empirical Findings and Social Services Policy. Social Work, 39, 649-657

Merriam, S.B. (1998). Qualitative Research and Case Study Applications in Education. San Francisco, CA: Jossey-Bass

National Coalition for the Homeless. (2011). Why are People Homeless? Retrieved September, 10, 2017, from http://www.nationalhomeless.org/factsheets/why.html 
National Center for Injury Prevention and Control. Costs of Intimate Partner Violence against Women in the United States. Atlanta (GA): Centers for Disease Control and Prevention; 2003

Nunez, R. (2000). Homeless in America: A Children's Story. Journal of Children and Poverty 6, (1), 51-72

O’Brien, J.E. (1971) Violence in Divorce-prone Families. Journal of Marriage and the Family 33(4): 692-698. In Rodriguez-Menes, J \& Safranoff, A. (2012). Violence against Women in Intimate Relations: A Contrast of Five Theories. European Journal of Criminology, 9(6), 584- 602

Olsen, L. (2016). Rules: The Good, the Bad, the Ugly. Retrieved July17, 2017, from http://www.wscadv.org/resourcesPublications.cfm

Olson, L. (2007). Battered Women's Shelters: Reflections. The Washington State Coalition against Domestic Violence

People v. Liberta (1984). 64 N.Y.2d 152, 474 N.E.2d 567, 485 N .Y.S.2d 207. URL: http://faculty.law.miami.edu/zfenton/documents/Peoplev.Liberta.pdf

Rafferty, Y., \& Shinn, M. (1991). The Impact of Homelessness on Children. American Psychologist 46(11), 1170-1179

Ridington, J. (1977-1978). The Transition Process: A Feminist Environment as Reconstitutive Milieu. Victimology: An International Journal, 2(3-4), 563-575 
Robert, A. (1998). The Organizational Structure and Function of Shelters for Battered Women and Their Children: A National Survey. In A. Robert (Ed.), Battered Women and Their Families (pp. 58-74). New York: Springer Rodriguez, R. (1998). Clinical Interventions with Battered Migrant Farm Worker Women. In J. C. Campbell (Ed.), Empowering survivors of abuse: Health care for battered women and their children, (pp. 271-279).

Thousand Oaks, CA: Sage

Rodman, H. (1972). Marital Power and the Theory of Resources in Cultural Context. Journal of Comparative Family Studies, 3(1), 50-69

Rodriguez-Menes, J \& Safranoff, A. (2012). Violence against Women in Intimate Relations: A Contrast of Five Theories. European Journal of Criminology, 9(6), 584- 602

Rudrappa, S. (2004). Radical Caring in an Ethnic Shelter: South Asian American Women Workers at Apna Ghar, Chicago. Gender \& Society, 18, 588-609

Sabar Ben-Yehoshua, N. (1990). Qualitative Research in Teaching and Studying. Givatayim: Masada (Hebrew). In Haj-Yahia, M., M. \&Cohen, H.C. (2009). On Lived Experience of Battered Women Residing in Shelters. Journal of Family Violence, 24 (2), 95-109

Schechter, S. (1982). Woman and Male Violence: The Visions and Struggle of the Battered Women's Movement. Boston: South End. In Sullivan, M. C., \& Gillum, T. (n.d). Shelters and Other Community-based Services for Battered Women and Their Children. Retrieved July, 25, 2017, fromhttps://cap.vaw.msu.edu/wp-content/uploads/2014/05/chapter13.pdf Schillinger, E. (1988). Dependency, Control, and Isolation: Battered Women and the Welfare System. Journal of Contemporary Ethnography 16 (January): 469-90 
Sedlak, A. J. (1988). Prevention of Wife Abuse. In Sullivan, M. C., \& Gillum, T. (n.d). Shelters and Other Community-based Services for Battered Women and Their Children. Retrieved July, 25, 2017, fromhttps://cap.vaw.msu.edu/wp-content/uploads/2014/05/chapter13.pdf

Shostack, A. L. (2001). Shelters for Battered Women and Their children: A Comprehensive Guide to Planning and Operating Safe and Caring Residential Programs. Springfield: Charles C. Thomas

Smyth, K. F., Goodman, L., \& Glenn, C. (2006). The Full-Frame Approach: A New Response to Marginalized Women Left Behind by Specialized Services. American Journal of Orthopsychiatry 76(4) 489-502

Social Issue Report. (2011, September). Empowering Victims of Domestic Violence. Retrieved July, 25, 2017, fromwww.rootcause.org/.../Empowering-Victims-of-DomesticViolence/Empowering $\% 20$

Stark, L. (1994). The Shelter as "Total Institution”: An Organizational Barrier to Remedying Homelessness. American Behavioral Scientist, 37(4), 553-562

Stermac, L., \& Paradis, E. K. (2001). Homeless Women and Victimization: Abuse and Mental Health History among Homeless Rape Survivors. Resources for Feminist Research/Documentation sur la Recherche Feministe, 28, 65-80

Straus, M. A., Gelles, R. J., \& Steinmetz, S. K. (1980). Behind Closed Doors: Violence in the American family. New York: Anchor Press. In Sullivan, M. C., \& Gillum, T. (n.d). Shelters and Other Community-based Services for Battered Women and Their Children. Retrieved July, 25, 2017, fromhttps://cap.vaw.msu.edu/wpcontent/uploads/2014/05/chapter13.pdf 
Sullivan, M. C., \& Gillum, T. (2001). Shelters and Other Community-based Services for Battered Women and Their Children. In C. M. Renzetti,, J. L. Endleson, \& R. K. Bergen (Eds.), Sourcebook on violence against women (pp. 247-258). California: Sage Publications

Timmer, D., A., Eitzen, D., S. \& Talley, K., D. (1994). Paths to Homelessness: Extreme poverty and the Urban Housing Crisis. Boulder, CO: Westview Press

Toro, P.A., \& Warren, M. G. (1998). Homelessness in the United States: Policy Considerations. Journal of Community Psychology, 27, 119-136

Tutty, L. M., Weaver, G., \& Rothery, M. A. (1999). Residents' Views of the Efficacy of Shelter Services for Assaulted Women. Violence against Women, 5, 898-925

United Nations Development Fund for Women. (2003). Not a Minute More: Ending Violence against Women. Retrieved July 26, from http://www.unifem.org/resources/item_detail.php?ProductID=7

Watts, C.\& Zimmerman, C. (2002). Violence against Women: Global Scope and Magnitude. The Lancet. Vol 359

Weinreb, L., \& Rossi, P. (1995). The American Homeless Family Shelter System. Social Service Review, 69, 1, 87

Wenzel, S. L., Tucker, J.S., Elliott, M.N., Hambarsoomians, K., Perlman, J., Becker, K., Kollross, C., \& Golinelli, D. (2004). Prevalence and Co-occurrence of Violence, Substance Use and Disorder, and HIV Risk Behavior: A Comparison of Sheltered and Low-income Housed Women in Los Angeles County. Preventive Medicine: An International Journal Devoted to Practice and Theory, 39, 617-624 
Williams, J. (1998). Domestic Violence and Poverty: The Narratives of Homeless Women. Frontiers: A Journal of Women Studies, 19, 143

Wright, J., D. (1989). Address Unknown: Homelessness in America. Hawthorne, NY: Aldine de Gruyter

Yllo, K., A. (1993). Through a Feminist Lens: Gender, Power, and Violence. In RodriguezMenes, J \& Safranoff, A. (2012). Violence against Women in Intimate Relations: A Contrast of Five Theories. European Journal of Criminology, 9(6), 584- 602 


\section{APPENDIX A: INTERVIEW GUIDE}

\section{Demographics}

1. Gender

2. Age

3. Race

4. Marital status

5. Occupation

a. What is your level of education?

b. How long have you stayed in the shelter?

\section{Interview Questions}

1. Please describe your experiences living here at (Name of shelter).

i. -What have been some positive experiences/negative experiences?

2. Please share with me any previous shelter encounters

- Do you feel safe here? Why or why not?

3. Please explain any form(s) of support (Physical, emotional, psychological, etc) you receive here at (Name of shelter).

-What form(s) of support has/have been very relevant to you?

4. Please describe any relationships you have built living here at (Name of shelter).

-Have you made friends with other residents? Staff?

5. Please explain how living here has impacted your family life. 
-What effect has it had on children (then can ask if they live with them at shelter)

Impact on extended family?

6. Please explain any learning experiences from the shelter that come into play when you are outside the shelter.

7. Please describe some ways, if any, which your experience living here at (shelter) could have been improved.

8. How similar/different are living conditions here at the shelter from your original residence?

-Do you have friends here who share similar/ different opinions?

9. Before coming to (name of shelter) what was your opinion about shelters? How has this changed since living here? 


\section{PLEASE READ!!!}

\section{Volunteer Research Opportunity}

\section{for female survivors of domestic}

\section{violence!}

A criminal justice master's student from Illinois State University is in need of volunteers to conduct a research study. She is interested in learning about the experiences of survivors of domestic violence living in shelters. Information gathered from your participation will help the researcher determine and design programming needed for those victimized, as well as provide guidance for future researchers and professors who teach in the area of Victimology. 
Participation in this study is completely voluntary. Any information provided by participants will be kept confidential and will have no effect on your participation in programming with any shelter. Thank you for your time and consideration of this matter. Information obtained from this study will be used solely for academic purposes.

If you are interested in participating or have any questions, please contact the researcher directly:

\section{Queencilla Hammond, Graduate Assistant}

Illinois State University

Campus Box 4670

Normal, IL 61790-4670

(309) 438-0097 


\section{APPENDIX C: VOLUNTARY INFORMED CONSENT FORM FOR INTERVIEW}

\section{Introduction}

Dr. Shelly Clevenger, Illinois State University, and I would like to invite you to participate in a research study. I ask that you please review the following information so that you can make an informed decision in regard to your participation in this project. If you choose to participate, please keep in mind that I would like for you to ask any questions, at any time, about this study, my intentions, and your role as a participant in this study.

\section{Purpose of Study}

The purpose of this study is to assess the experiences of women who have suffered intimate partner violence and are staying at shelters. Specifically, I am interested in knowing your subjective experiences as a resident of the shelter and how you believe these experiences can be improved. The data will be used for publications in criminological journals, conference presentations, and to complete a thesis.

\section{Procedures}

I will be asking questions about your shelter experiences. Interviews are expected to take about an hour of participants' time. However, this is only an estimate, and interviews could be shorter or last longer. With your permission, interviews will be recorded. As soon as interviews are transcribed the recordings will be deleted. I will use quotes in my write up of my research, but no identifying information will be used in future publications. To protect the participants, de-identified data will be stored under lock and key for a period of three years. Identified data is destroyed once transcription occurs. 


\section{Risks/Discomforts}

The primary risk of this study is the potential loss of confidentiality; however, the researchers will do everything within their power to ensure this does not happen. The issue of loss of privacy is also a foreseeable risk even in an event that participants do not answer the questions but reside in the shelter and considering the study. In addition, participants may have concerns that sharing negative experiences may jeopardize receiving services from the shelter. The researchers will ensure that no information in any form of potential participants in the shelter is disclosed to anyone else if not solely for academic purposes. Participants will also be assured that no information they share including negative experiences will be connected to their names directly in any situation and researchers will also ensure that no identifiable information is shared with anyone involved with the running the shelter.

During the interviewing process, you will be asked questions pertaining to your experiences while staying at the shelter. These experiences maybe both negative and positive. There is a possibility that the interview can cause emotional distress as you will be discussing sensitive and potentially painful memories. If at any time you feel you cannot continue with the interview or wish to not answer certain questions, your requests will be granted by the interviewer. If you wish to withdraw, all information will be destroyed, if you so wish. You will not experience any negative effects for doing so. Interview sessions will consider the comfort level of the participants and respect each participant's wishes. Interviews will be coded with identification numbers, so that your actual name will not be used. This will help to maintain confidentiality. Information given to me will be stored securely and used for research purposes in academia and to assist homeless shelters to improve their services. Your name will not be disclosed in association with your information given during the interview. However, we need to make you aware that in certain research studies, it is our legal and ethical responsibility to report [situations of child abuse, child neglect, or any life-threatening situation] [illegal activity on the ISU campus, campus- 
controlled locations, or involving ISU students] to appropriate authorities. However, we are not seeking this type of information in our study nor will you be asked questions about these issues.

Some participants may find it cathartic to be given a platform to discuss these experiences and voice their opinions. Additionally, your participation will provide the researchers with information that could potentially better services made available to shelter residents.

\section{Participation}

Participation in this study is completely voluntary. Your decision not to participate will have no negative consequences. If you are willing to participate, please sign and date the attached form. A copy of this form will be kept on file in Dr. Clevenger's office on Illinois State's campus. I will provide you with a copy of this form to keep. If you do not wish to proceed with participation in this study, I would like to thank you for your time and consideration of this matter.

Name (Please Print)

Signature

Date 


\section{APPENDIX D: VOLUNTARY CONSENT FORM FOR FACE-TO-FACE INTERVIEW}

After reviewing the following information provided by the researcher, I volunteer to participate in this research study and have my interview audio recorded.

Signature

Date

After reviewing the following information provided by the researcher, I volunteer to participate in this research study without having the interview audio recorded.

Signature

Date

I hereby certify that I have explained to the participant the nature of this study, potential benefits, and possible risks associated with participation, and have given the opportunity for questions to be asked and answered in regard to this study.

Signed:

Date:

Contact information: 


\section{Queencilla Hammond Dr. Shelly L. Clevenger}

Illinois State University

Department of Criminal Justice Sciences

Campus Box 5250

Normal, IL 61790
Illinois State University

422 Schroeder Hall

Normal, IL 61761

Please direct questions about research participants' rights and/or a research related injury or adverse effects to:

The Research Ethics \& Compliance Office

(309) 438-2529

rec@ilstu.edu 
APPENDIX E: WITHDRAWAL STATEMENT

Please place an $X$ on the line next to which statement reflects your wishes and fill out the corresponding information.

Withdrawal Statement to allow use of data

I have chosen to withdraw from this study, but give my

permission to the researcher, Queencilla Hammond, to use any data collected prior to my decision to withdraw from this study.

Name (Please Print)

Signature

Date

I hereby certify that I have explained to the participant that this information will not be used and any file linking names to data will be destroyed.

Signed: Date: 


\section{Queencilla Hammond}

Illinois State University

Department of Criminal Justice Sciences

Campus Box 5250

Normal, IL 61790

\section{Dr. Shelly L. Clevenger}

Illinois State University

422 Schroeder Hall

Normal, IL 61761 